\title{
Post-Kellwasser event recovery and diversification of phacopid trilobites in the early Famennian (Late Devonian)
}

\author{
RAIMUND FEIST
}

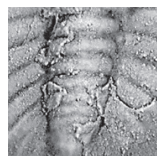

\begin{abstract}
While no Frasnian phacopid genera are known to survive the terminal Frasnian Kellwasser extinction event, recovery of phacopids in the early Famennian is characterised by one of the highest origination rates of the clade. In this study species and subspecies currently known are updated with regard to their age distribution according to conodontbased bio-zonation. They occur in representative sites including Sessacker (Rhenish Slate Mountains), Wieda (Harz), McWhae Ridge (Canning Basin, Western Australia), Beni Abbès (Algerian Sahara) and Montagne Noire (Southern France). More than two-thirds of the taxa are reduced-eyed or blind, which might indicate adaptation to deep offshore habitats. A few taxa with Phacops-like kidney-shaped eyes with many lenses represent shallower environments in the photic zone. The fauna is characterised by different features of the ventral cephalic doublure due to the presence or absence of individualized anterior border, vincular furrow and postvincular doublure. Phyletic affiliation to Frasnian taxa remains difficult to assess until these are better known for their diversity in various habitats. Chlupacops may be a possible ancestor of taxa with cephalic anterior border such as Nephranops and Houseops, while Cryphops and Trimerocephalus may be rooted in Acuticryphops as previously thought. The systematic part is devoted to diagnoses and descriptions that are completed by new morphological criteria leading to some taxonomic re-assignments. The following taxa are new: Nephranops (Nephranops) angerae sp. nov., Nephranops (Maternia) occitanicus subgen. et sp. nov., Pulvinocephalus gen. nov., P. (Pulvinocephalus) steinachensis triangulus subgen. et subsp. nov., P. (Cryphopsides) ovatus subgen. et sp. nov., P. (?Cryphopsides) walliseri ?subgen. et sp. nov., Trifoliops septimanicus sp. nov., Struveops wiedaensis sp. nov. - Key words: phacopid trilobites, Famennian, biostratigraphy, phylogeny, morphology, systematics.
\end{abstract}

FeIST, R. 2019. Post-Kellwasser event recovery and diversification of phacopid trilobites in the early Famennian (Late Devonian). Bulletin of Geosciences 94(1), 1-22 (7 figures). Czech Geological Survey, Prague. ISSN 1214-1119. Manuscript received October 2, 2018; accepted in revised form March 5, 2019; published online March 21, 2019; issued March 31, 2019.

Raimund Feist, Institut des Sciences de l'Evolution, Laboratoire de Paléontologie, Université Montpellier, pl. E. Bataillon, F 34095 Montpellier, France; raimund.feist@umontpellier.fr

The Frasnian was an age of severe restriction in trilobite diversity triggering one of the highest extinction rates in the Late Palaeozoic (Lerosey-Aubril \& Feist 2012). This is essentially due to the terminal Frasnian global Kellwasser crises (Feist 1991, McNamara \& Feist 2016). The peak of the main level of mass extinction, i.e. the Upper Kellwasser Horizon, coincides with the FrasnianFamennian boundary as defined in 1993 by IUGS at the base of the Lower triangularis Zone (Klapper et al. 1993). The Famennian starts now much earlier than at the first appearance of the goniatite Cheiloceras (Ziegler 1971) in the Late triangularis Zone which was previously used to define the boundary. Accordingly, and after restriction of both Nephranops and Cryphops to the early Famennian (Crônier \& Feist 2000; Feist et al. 2009, p. 16), phacopids lost all remaining three genera recognized to date from the late Frasnian: Chlupacops at the base of the
Lower Kellwasser Horizon, and Trimerocephaloides and Acuticryphops at the base of the Upper Kellwasser Horizon (Feist et al. 2009, McNamara \& Feist 2016). Thus, and in contrast to previous thinking (Alberti 1970, Feist 1991), phacopids were severely affected by the Kellwasser crises. Elucidation of phylogenetic relationships between taxa prior to and following the terminal Frasnian global biocrises is hindered by the scarcity of recorded trilobite taxa, in particular from shallow near-shore environments. Further difficulties lie in the fact that age attribution of phacopids previously followed ammonoid-based chronology and that modern biostratigraphical assignments of taxa to conodont zones have been achieved only locally (e.g. Ziegler 1962; Lütke 1968; Feist et al. 2009, 2016). For instance, important Uralian taxa close to the FrasnianFamennian boundary, such as "Phacops (Cryphops)" latilimbatus Maximova, 1955 [assigned herein to the new 
taxon Pulvinocephalus (Cryphopsides) gen. and subgen. nov.] and "Phacops (Phacops)" pronini Maximova, 1955 [assigned with question to Houseops by Feist et al. (2009)] were recovered from the Crickites Zone and were considered of Frasnian age (Maximova 1955, p. 192). However, these taxa possibly occur in the topmost part of this zone that, devoid of Crickites and preceding the first occurrence of Cheiloceras ("post doI $\delta$ " interval; Ziegler 1971), has now become basal Famennian. This is proven at least for latilimbatus from the Barma horizon in the SW Uralian Bol'shaya Barma section that yields conodonts from the Early and Middle triangularis Zones (Abramova \& Artyushkova 2004, Tagarieva 2013). In this context, an attempt is made to update and revise both known and new post-event early Famennian phacopids, with respect to their systematic definition and their temporal occurrence within the conodont zonation (Fig. 1). In addition to the description of new taxa, systematic palaeontology focusses on previously unconsidered or newly observed criteria that necessitate taxonomic re-assignments.

\section{Distribution in time and space}

Post-event recovery and diversification of phacopids during the early Famennian (Early triangularis through Early marginifera Zones), while stepwise, is rather important: at the present state of knowledge 11 genera $(+2$ subgenera) with 38 species ( +3 subspecies) successively appear within the time interval of some 6 m.y. (Kaufmann 2006) versus only 6 genera with 12 species during the entire Frasnian of 7 m.y. duration. Currently known taxa and their attribution to conodont zones are shown in Fig. 1 (some attributions remain tentative).

While Famennian phacopids are distributed worldwide with the exception of the Americas (Chlupác 1975, Crônier \& François 2014), fewer than half of the genera (i.e. Trimerocephalus, Houseops, Nephranops, Pulvinocephalus and Trifoliops) have intercontinental significance. The others are virtually restricted to a single cratonic margin. However, other discoveries in unexploited areas may reveal a wider distribution of currently known taxa. The most significant phacopid assemblages that occur in some representative conodont-dated sites are as follows.

On the Avalonian margin of the Old Red continent early Famennian phacopids are best represented in the Rhenish Slate Mountains though they are dated by conodonts only in a few localities. Many taxa occur in red cephalopodbearing calcilutites at the famous Sessacker locality near Oberscheld, SE Rhenish Slate Mountains (Emmrich 1844; Richter \& Richter 1926; Matern 1927, 1931). The specimens were recovered from trenched sections and their stratigraphical position was dated according to associated ammonoids. More recently, several new trenches have been investigated to establish conodont biozonations across the Frasnian-Famennian boundary and in the lower Famennian (Ziegler 1962, Feist \& Schindler 1994, Schülke 1995). In particular, conodonts from Matern's and Lippert's trilobite samples (Senckenberg collections) were determined by Ziegler (1962) and, in addition, those of my own collections by Corradini and Girard (contributions herein). These investigations made it possible to assign occurrences of diversified phacopid faunas to conodont zones. It should be noted that, with the exception of the Early triangularis Zone, all other early Famennian conodont zones can be recognised by phacopids: Early marginifera - Struveops wiedaensis sp. nov.; rhomboidea - Dienstina diensti (Richter \& Richter, 1923); Late crepida to marginifera - Trimerocephalus mastophthalmus (Richter, 1856); Middle crepida to Late crepidaCryphops cryptophthalmus (Emmrich, 1844); Early crepida to Early marginifera - Ductina ductifrons (Richter \& Richter, 1923); Early crepida to rhomboidea - Pulvinocephalus $(P$.) steinachensis triangulus gen., subgen. et subsp. nov.; Late triangularis to Late crepida - Pulvinocephalus (Cryphopsides) ovatus gen., subgen. et sp. nov.; Middle triangularis to Early crepida - Nephranops (Maternia) dillanus Richter \& Richter, 1926; Middle to Late triangularis - Nephranops (Nephranops) incisus (Roemer, 1866).

In the Harz Mountains several localities near Wieda, in particular the Stöberhaifahrweg, yield well preseserved phacopids that were dated by conodonts (Lütke 1968): Early marginifera - Struveops wiedaensis sp. nov.; Early marginifera - Pulvinocephalus (Pulvinocephalus) cf. steinachensis (Richter \& Richter, 1926); Late crepidaTrimerocephalus mastophthalmus (Richter, 1856); Late crepida - Ductina ductifrons (Richter \& Richter, 1923); Late crepida - Houseops miserrimus wiedensis (Lütke, 1968).

On the southeastern margin of Gondwana, the McWhae Ridge area in the Canning Basin, Western Australia, offered a diverse fauna of phacopids from reef-slope environments (Feist et al. 2009). These characterise several conodont zones (det. G. Klapper): rhomboidea - Trimerocephalus mimbi Feist, 2009 in Feist et al. (2009); rhomboidea Trimerocephalus tardispinosus Feist \& Becker, 1997; Uppermost crepida to Lower rhomboidea - Babinops planiventer Feist \& Becker, 1997; Upper crepida Babinops minor Feist, 2009 in Feist et al. (2009); Lower to Middle crepida - Houseops canningensis Feist, 2009 in Feist et al. (2009); Upper triangularis - Houseops beckeri Feist, 2009 in Feist et al. (2009); Upper triangularis Houseops sp. A Feist, 2009 in Feist et al. (2009).

On the north-western margin of Gondwana, in the Beni Abbès area of the Algerian Sahara, numerous phacopids recently brought to light (Crônier et al. 2013, Feist et al. 
N. (Nephranops) Richter \& Richter, 1926

$N$. (N.) incisus (Roemer, 1866)

$N$. (N.) aff. incisus (Roemer, 1866)

$N$. (N.) angerae sp. nov.

N. (Maternia) subgen. nov.

$N$. (M.) dillanus Richter \& Richter, 1926

$N$. (M.) occitanicus sp. nov

Pulvinocephalus gen. nov.

P. (Pulvinocephalus) subgen. nov.

P. (P.) steinachensis (Richter \& Richter, 1926)

$P$. (P.) steinachensis triangulus subsp. nov.

$P$. (Cryphopsides) subgen.nov.

$P$. (Cr.) latilimbatus (Maximova, 1955)

$P$. (Cr.) ovatus sp. nov.

$P$. (?Cr.) walliseri $\mathrm{sp}$. nov.

Houseops Feist et al., 2009

$H$. beckeri Feist et al., 2009

$H$. sp. A Feist et al., 2009

H. canningensis Feist et al., 2009

H. miserrimus miserrimus (Drevermann, 1901)

H. miserrimus wiedensis (Lütke, 1968)

?H. nalivkini (Maximova, 1955)

?H. ocellatus (Perna, 1915)

?H. tamtertensis Crônier et al.,2013

Cryphops Richter \& Richter, 1926

C. cryptophthalmus (Emmrich, 1844)

Ductina Richter \& Richter, 1931

D. ductifrons (Richter \& Richter, 1923)

Dienstina Richter \& Richter, 1931

Di. diensti (Richter \& Richter, 1923)

Di. limaria (Perna, 1915)

Babinops Feist \& Becker, 1997

B. minor Feist et al., 2009

B. planiventer Feist \& Becker, 1997

Trifoliops Crônier, 2003

Tr. trifolius (Osmólska, 1958)

Tr. septimanicus sp. nov.

Tr. cronieri Feist, 2016

Trimerocephalus McCoy, 1849

T. mastophthalmus (Reinhard Richter, 1856)

T. caecus (Gürich, 1896)

T. chopini Kin \& Błażejowski, 2013

T. cryptophthalmoides Maximova, 1955

T. lacunosus Pfeiffer, 1959

T. lelievrei Crônier \& Feist, 1997

T. shotoriensis Feist, 2003

T. mahboubii Feist, 2016

T. mimbi Feist et al., 2009

?T. nigritus Crônier, 2003

T. tardispinosus Feist \& Becker, 1997

T. vodorezovi Maximova, 1955

Enigmapyge Feist, 2016

E. marhoumensis, 2016

Struveops Crônier \& Feist, 2000

$S$. wiedaensis sp. nov.

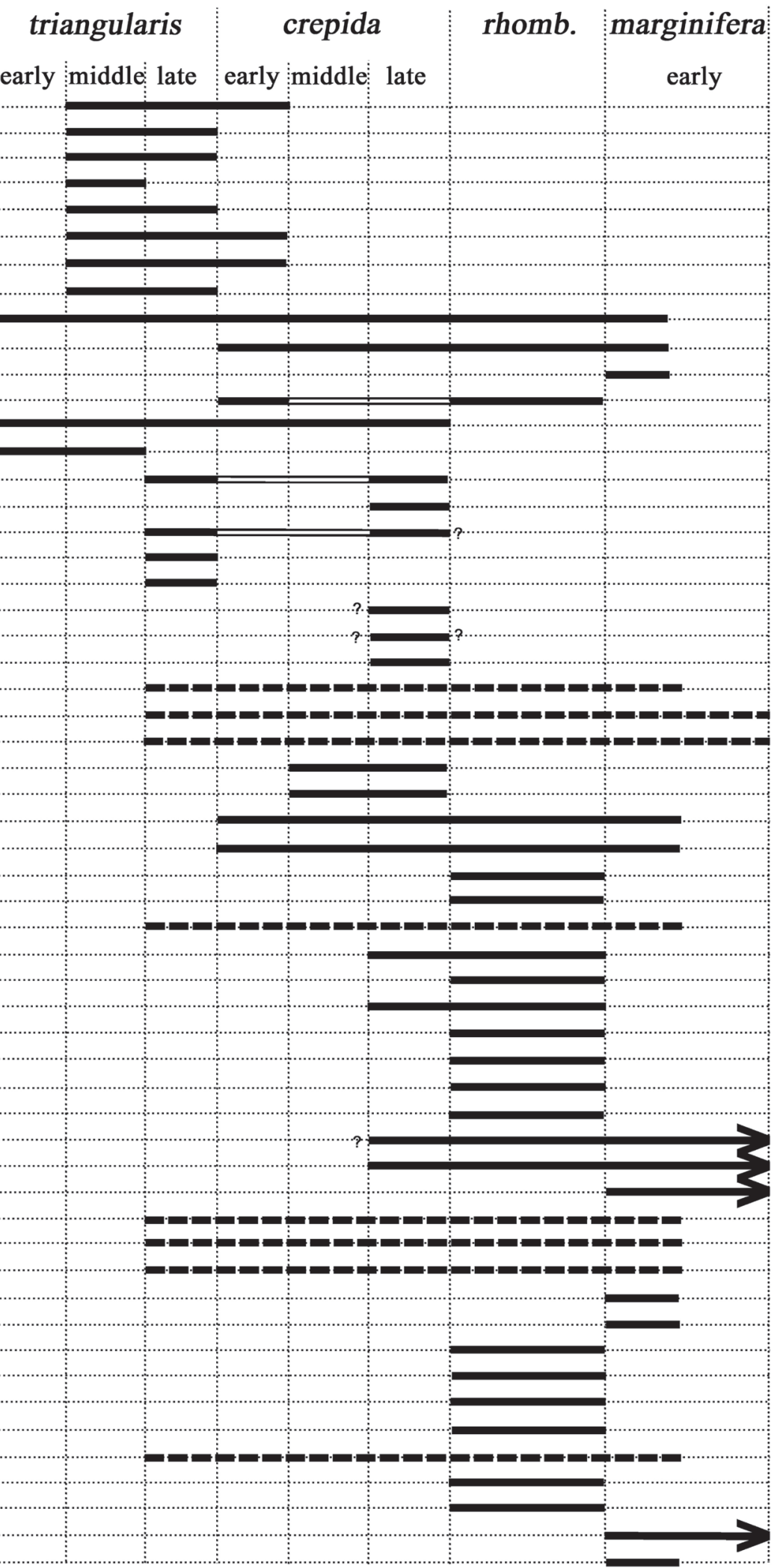

Figure 1. Range chart of early Famennian phacopids according to conodont biozonation (Late/Latest crepida Zones and rhomboidea Zones undifferentiated). Explanation: full lines - known ranges; empty lines - inferred occurrences; dashed lines - undifferentiated ranges; question marks possible extensions; arrows - extensions beyond early Famennian. 
2016) have been dated by conodonts (det. C. Corradini \& C. Girard): Early marginifera - Trimerocephalus caecus (Gürich, 1896); Early ?marginifera - ?Houseops tamtertensis Crônier, 2013 in Crônier et al. (2013); rhomboidea - ?Houseops cryphoides (Richter \& Richter, 1926) (= Houseops aff. miserrimus Drevermann, 1901); rhomboidea - ?Trimerocephalus nigritus Crônier, 2003; Early rhomboidea - Trimerocephalus mahboubii Feist, 2016 in Feist et al. (2016); Early rhomboidea - Trifoliops trifolius (Osmólska, 1958); Early rhomboidea - Trifoliops cronierae Feist, 2016 in Feist et al. (2016); Early rhomboidea - Enigmapyge marhoumensis Feist, 2016 in Feist et al. (2016).

In the Montagne Noire the following taxa were dated by conodonts (Girard et al. 2014): Late rhomboidea Trifoliops septimanicus sp. nov.; Middle to Late triangularis - Nephranops (Nephranops) angerae sp. nov.; Middle to Late triangularis - Nephranops (Maternia) occitanicus sp. nov.

In conclusion, according to known occurrences, most early Famennian conodont zones are characterised by phacopid associations.

\section{Characteristic morphological features}

Evolutionary trends in early Famennian phacopids include the reduction of the visual complex, i.e. forward migration and lowering of the palpebral lobes, as well as regression of the visual surface and optical devices until their complete effacement in blind taxa. In this regard, three groups can be distinguished. Firstly, there are "normally" sighted taxa that exhibit the ancestral phacopid configuration of the palpebral area with visual surfaces carrying numerous lenses. They attain up to $27 \%$ of the total number of species and sub-species considered. The earliest representatives of Pulvinocephalus (Cryphopsides) that are characterised by kidney-shaped eyes occur in shallow brachiopodrich bioclastic limestones in the South Urals (Maximova 1955). Australian taxa from reef-slope environments of the Canning Basin such as Babinops and Houseops exhibit kidney-shaped palpebral lobes and eyes, though those of the latter are smaller and advanced in comparison to Phacops. Uralian taxa assigned with question to Houseops occur in shallower brachiopod-yielding environments. A particular case is represented by Nephranops, inhabitant of deeper offshore cephalopod limestones and marls. The palpebral lobes have become low kidney-shaped swells and the wide visual surface, generally without lenses, is defined by dorsally convex palpebral sutures in lateral view. This is an outstanding case of in situ disappearance of functional optic devices likely due to adaptation to levelbottom environments below the photic zone. The second category comprises sighted taxa with advanced reduction of the palpebral lobe. This has become a small bulged area close to the antero-lateral edge of the genal field with small elliptical or circular visual surfaces exhibiting few lenses. This "cryptophthalmus" configuration (Richter \& Richter 1926) occurs in $12 \%$ of early Famennian taxa, exemplified by Cryphops, Dienstina and late forms of Pulvinocephalus (Cryphopsides) that lived in offshore cephalopod limestone habitats in moderate water depth within light penetration. Struveops is outstanding in the presence of a far-forward shifted, tiny bulged palpebral area without lenses. A majority (56\%) of the remaining early Famennian species and subspecies of which the genal fields are known (i.e. Ductina, Trifoliops, Trimerocephalus and Pulvinocephalus (Pulvinocephalus) are blind. Palpebral lobes and visual surfaces are absent on the vaulted genal field, and minute crescent-shaped dorsal librigenae are defined by facial sutures running onto the anteriormost genal field, in the border furrow (Trimerocephalus) or along the outer antero-lateral border (Ductina). These taxa might have adopted a semiendobenthic lifestyle under muddy substrate conditions at the limits of light-penetration.

In earlier epochs, singular cases of blindness in phacopids are known [e.g. in the late Silurian Denckmannites (Schrank 1973) or in the Middle Devonian Illaenula (Chlupáč 1977, Basse \& Müller 2000)]. But a general trend of eye-reduction leading to a majority of blind taxa that cohabit with sighted ones in the same offshore environment is outstanding, and characterises the early Famennian phacopid communities. In this regard, the occurrence of demonstrably 23 blind taxa out of 41 species and sub-species marks a peak period of eyereduction within the evolutionary history of phacopids.

The ventral side of the ankylosed librigenae (i.e. the ventral doublure), in particular the inner parts anteriorly and below the frontal suture, also underwent considerable morphological variations. These are related to the presence or absence of a protruding anterior cephalic border which, in case of its regression, is replaced by a backwardly oriented flat pre-vincular doublure, and, additionally, the presence or absence of both the vincular furrow and the postvincular doublure (Fig. 2). In most early Famennian taxa (i.e. Babinops, Houseops, Nephranops, Pulvinocephalus, Trifoliops and Dienstina) a convex anterior border is differentiated from the front of the glabella by its own vault and forward extension (Fig. $3 \mathrm{~A}-\mathrm{D}, \mathrm{F}-\mathrm{H})$. It is defined ventrally by an edge or break in slope against the vincular furrow when the latter is present. In Babinops, Nephranops (Nephranops) and Dienstina no vincular furrow is developed adaxially and there is an undivided ventral doublure between the posterior edge of the cephalic border and the hypostomal suture (Fig. 3A, D). In Cryphops, Trimerocephalus, Struveops and Ductina no anterior cephalic border can be defined as the 

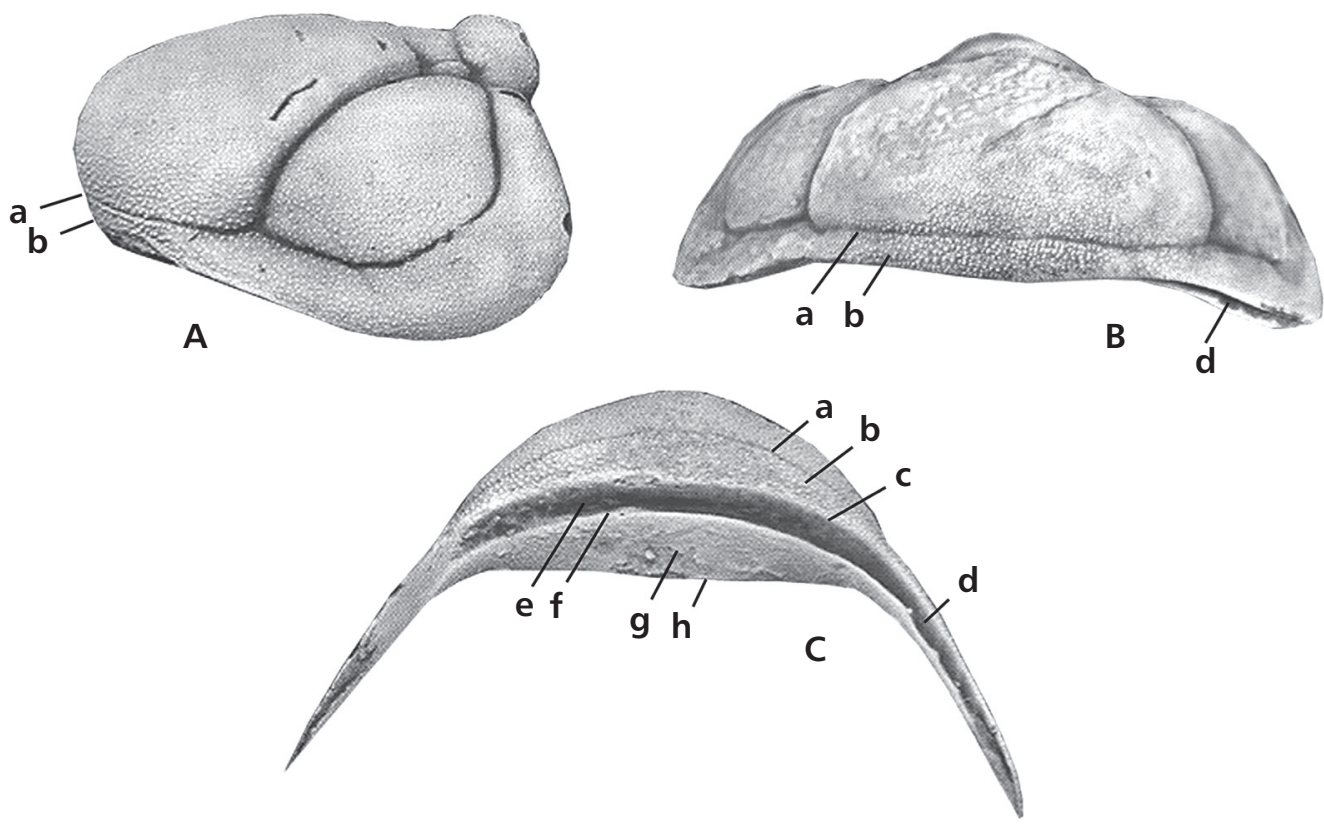

Figure 2. Terminology of lateral (A), anterior (B) and ventral (C) views of Trimerocephalus mahboubii Feist, 2016 in Feist et al. (2016) - anterior suture (a); pre-vincular doublure (b) corresponding to anterior border; posterior edge of pre-vincular doublure (c); lateral notches of vincular furrow (d); vincular furrow (e); anterior edge of postvincular doublure (f); postvincular doublure (g); hypostomal suture (h).

profile of the anterior glabellar vault extends continuously downwards across the suture; the pre-vincular doublure is backwardly directed (Fig. 3E, I, J) until reaching the vincular furrow. The latter is absent in Struveops and Ductina where the ventral doublure remains undivided (Fig. 3E). The vincular furrow varies in depth and sagittal length: it is deep and narrow (sag.) in Houseops, Nephranops (Maternia), Pulvinocephalus (Cryphopsides), Cryphops and Trimerocephalus, very wide and profound in Trifoliops (Fig. 3H). The postvincular doublure is generally as long as or up to three times longer (sag.) than the vincular furrow. In Trifoliops and Pulvinocephalus (Cryphopsides) it is shorter (Fig. 3G, H), and it is absent in Cryphops (Fig. 3I).

Apparently, features of the ventral doublure are not related to evolutionary changes that concern eyereduction and the course of the suture on the dorsal side of the librigenae. This is obvious when comparing normally-

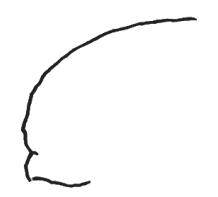

A

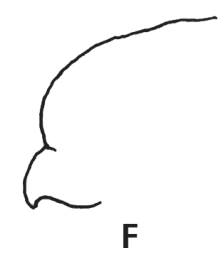

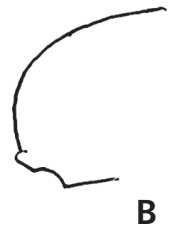

B

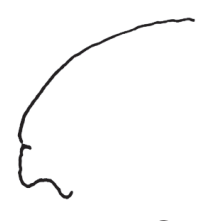

G
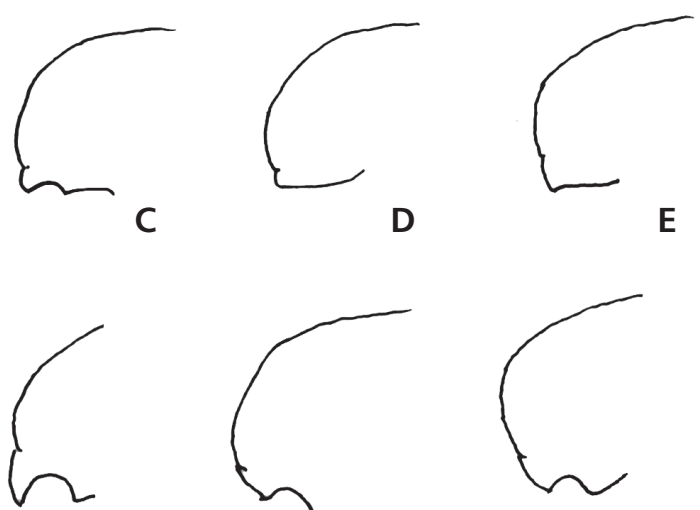

H
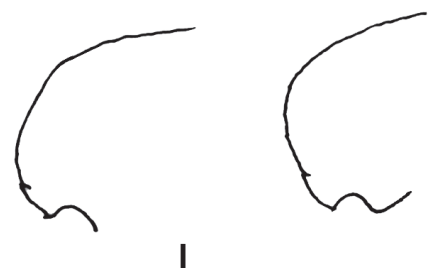

J

Figure 3. Diagrammatic representation of sagittal profiles of anterior part of cephalon in representative early Famennian phacopid taxa. $\bullet$ A - Babinops planiventer Feist \& Becker, 1997. • B - Houseops canningensis Feist, 2009 in Feist et al. (2009). • C - Nephranops (Maternia) dillanus Richter \& Richter, 1926. • D - Nephranops (Nephranops) incisus (Roemer, 1866). • E - Struveops wiedaensis sp. nov. • F - Pulvinocephalus (Pulvinocephalus) steinachensis triangulus gen. et sp. nov. $\bullet \mathrm{G}-$ Pulvinocephalus (?Cryphopsides) walliseri gen., subgen. et sp. nov. • H - Trifoliops septimanicus sp. nov. • I - Cryphops cryptophthalmus (Emmrich, 1844). • J - Trimerocephalus mimbi Feist, 2009 in Feist et al. (2009). 
sighted taxa of Houseops and Babinops, the former having deep vincular furrows that are absent in the latter. Presence or absence of the vincular furrow might reflect a different life-style: tighter fit of the pygidial edge during enrolment is reached in the first case. It is difficult to explain at this stage the co-occurrence of species of Nephranops (Maternia) that exhibit deep vincular furrows with those of Nephranops (Nephranops), in which these structures are almost effaced. Indeed, both taxa are associated at Sessacker (Rhenish Slate Mountains), Rübeland (Harz Mountains) and Montagne Noire (southern France) in similar offshore cephalopod-yielding limestones.

\section{Questions about phyletic affiliations}

The earliest Famennian phacopids, Pulvinocephalus (Cryphopsides) and Nephranops, appeared shortly after the Kellwasser Extinction Event. They must have been derived from ancestral pre-Kellwasser lines, but their origin remains cryptic. Indeed, the cushion-like advanced configuration of the cephalic anterior border that characterises the former is unknown in any earlier phacopid. Likewise, Nephranops-type eye reduction with maintenance of a wide visual field without lenses is not known from earlier periods. However, other general cephalic traits are shared with diagnostic features of Frasnian taxa of Chlupacops, especially with C. cryphoides (Richter \& Richter, 1926) and C. aff. cryphoides (in Feist et al. 2016). These traits are in particular advanced, reduced palpebral lobes and, in Nephranops (Maternia), concave postvincular doublures as well as the outline of the multi-segmented pygidium. Despite the absence of transitional forms between both entities that might have existed shortly before or contemporaneously with the Kellwasser events, an origin of Nephranops from Chlupacops-derived taxa might best be envisaged. On the other hand, as stated earlier (Feist et al. 2009, p. 16), Nephranops and Houseops are closely related and may have had a common ancestry to be searched for among late representatives of Chlupacops.

In contrast to phacopids with a differentiated anterior cephalic border that are the first to appear after the Kellwasser events, Famennian representatives with a backwardly directed pre-vincular doublure do not occur earlier than in the Middle crepida Zone. The late appearance of Trimerocephalus in particular leaves a considerable gap of record after the morphologically closest Acuticryphops that is last present in the terminal Frasnian linguiformis Zone preceding the Upper Kellwasser Extinction. Nevertheless, a direct phyletic lineage between both taxa has been suggested (Chlupáč 1977, Feist 1995). Richter \& Richter $(1926,1955)$ considered Cryphops the direct ancestor of the slightly younger Trimerocephalus, but this view is contradicted by different features of the pygidium (unknown to the Richters) and of the ventral postvincular doublure. On the other hand, the virtual absence of morphologically intermediate evolutionary states of eyeregression between the sighted Acuticryphops and the blind Trimerocephalus during a long period of some 2 m.y. calls in question the existence of direct links between both taxa. Alternatively, both Cryphops and Trimerocephalus may have resulted from iterative evolution, descending from unknown survivors of the Kellwasser crises. In both scenarios the question of ancestry remains problematic and currently unsolved.

In conclusion, the Late Kellwasser Event accelerated the general decline of phacopids that characterised their evolution during the Frasnian. It is striking that no species and no genera are recognised to cross the FrasnianFamennian boundary. In contrast, phacopids experienced the highest origination rate during the early Famennian.

\section{Systematic Palaeontology}

Terminology follows Whittington \& Kelly (1997) and Feist et al. (2016).

Depository: SMF - Senckenberg Museum Frankfurt; UM-IP - University of Montpellier, Invertebrate Palaeontology; BGRB - Bundesanstalt für Geologie und Rohstoffe Spandau (former Zentral Geologisches Institut Berlin); MB.T - Naturkunde Museum Berlin.

\section{Genus Nephranops Richter \& Richter, 1926}

Type species. - Phacops (Trimerocephalus) incisus Roemer, 1866; Rübeland (Harz Mountains), Germany.

Diagnosis. - phacopid with low kidney-shaped palpebral lobes; wide visual surface, generally without lenses, defined by dorsally convex palpebral sutures in lateral view; vincular structure un-notched distally; pygidium with narrow, long axis composed of 7-9 rings, not reaching posterior margin.

Remarks. - After reassignment of Phacops (Trimerocephalus) miserrimus Drevermann, 1901 and, tentatively, Trimerocephalus ocellatus Perna, 1915 to Houseops Feist, 2009 in Feist et al. (2009), the definition of Nephranops by Richter et al. (1959) is emended. Taxa here included in Nephranops are characterised by kidney-shaped visual surfaces, generally devoid of lenses. Only the holotype specimen of the type-species and one specimen of the new taxon N. (Maternia) occitanicus sp. nov. have two residual lenses on the right side only (Fig. 4F). As pointed out by Richter \& Richter (1926, p. 127), the posterior edge of the 
vincular furrow in Nephranops, though rather smooth in the type species, and as high as the anterior edge in lateral view, is situated far back. In comparison, the vincular structure is more forwardly projected in Phacops. Taking into account the distinct diagnostic characters, both the configuration of the ventral side of the cephalon and the outline and shape of the pygidial axis, two subgenera are discriminated: $N$. (Nephranops) and N. (Maternia) subgen. nov.

Subgenera included. - N. (Nephranops), N. (Maternia) subgen. nov.

\section{Subgenus Nephranops (Nephranops) Richter \& Richter, 1926}

Diagnosis. - Anterior glabellar lobe not overhanging upturned anterior border; antero-lateral borders of cephalon flat with sharp edges; vincular furrow almost inconspicuous adaxially with poorly defined posterior edge; postvincular doublure very long (sag.), slightly vaulted with straight hypostomal suture; pygidial length equals half width, axis low, narrow with 9 rings and long terminal piece, pointed behind with crested tip, separated from posterior edge by shallow marginal depression; wide pleural field with 7 ribs composed of markedly distinct bands, the anterior almost reaching antero-lateral margins; posterior margin sharpedged without rim.

Occurrence. - Rhenish Slate Mountains, Harz, Thuringia, Montagne Noire, Morocco.

Species included. - N. (Nephranops) incisus (Roemer, 1866), Harz Mountains, Rhenish and Thuringian Slate Mountains, Holy Cross Mountains, $N$. (N.) sigmoidalis sp. nov., Montagne Noire; $N$. (N.) aff. sigmoidalis, central Hercynian Morocco; all from early Famennian Middle and Late triangularis zones.

\section{Nephranops (Nephranops) incisus (Roemer, 1866)}

Figures 3D; 4A-L, S-U

1866 Phacops (Trimerocephalus) incises; Roemer, p. 212, pl. 35, fig. 4.

1869 Proetus Münsteri. - Richter (Reinhard), p. 391.

1926 Phacops (Nephranops) incisus incisus. - Richter \& Richter, p. 149 , pl. 8, fig. 48, pl. 9, figs 49, 50 (see earlier synonymies here).

1954 Perliproetus? münsteri. - Pfeiffer, p. 33, pl. 1, figs 1, 2.

1954 Phacops (Nephranops) incisus incisus. - Pfeiffer, p. 39, pl. 2, fig. 1.

1970 Nephranops incisus incisus. - Alberti, p. 153, fig. 3.

2007 Nephranops incisus incisus. - Crônier, p. 685, figs 2-5.

2009 Nephranops incisus. - Feist et al., p. 14.

2018 Nephranops incisus. - Feist \& Weyer, p. 204, fig. 2a-h.
Material. - Cephalon from Sessacker figured by Richter \& Richter (1926, pl. 9, fig. 49), SMF RX 565a1, refigured herein; new material from Sessacker: coll. Lippert in Ziegler (1962), cephalon SMF 97026, pygidium SMF 97027, trench II, bed 25, Middle triangularis Zone; cephalon SMF 97028, pygidium SMF 97029, trench VI, bed 28a, Late triangularis Zone (after Schülke 1995); cephalon SMF 97030, coll. Denckmann, Marburg.

Diagnosis. - Cephalic axial furrows straight, frontal lobe of glabella not overhanging anterior border, of semicircular outline; anterior border furrow deep; pygidium of semicircular to sub-pentagonal outline, slightly truncated behind, axis with straight axial rings; pleural ribs not extending to lateral edges; postero-lateral border region defined against pleural field by break in slope, circumscribing inconspicuous border depression. Sculpture: low tiny granules.

Description. - The outer edge of anterior border coincides with anterior edge of vincular furrow. The latter represents a rather faint depression with flat bottom that extends abaxially without deepening, being framed by slightly thickened anterior and posterior edges. Distally, the flat bottom of the vincular furrow is provided with faint, oblique, almost inconspicuous ridges that join the edges of the furrow. They may delimit relicts of notches of the vincular structure. Pygidium sub-pentagonal, length (including articulating halfring) equal to half width. Posterior outline slightly truncated. Posterolateral edges are flat and sharp. Axis narrow, of moderate height with slightly depressed lateral profile, $9+1$ straight axial rings of equal length, the anterior ones with sigmoidal pseudoarticulating halfrings that encroach on preceding ring; terminal piece long, triangular, conspicuously crested, pointed behind, remaining distant from posterior edge of pygidium. Axial furrows markedly divergent anteriorly, thereafter straight with weak taper as far as terminal piece, converging more strongly around terminal piece as far as the tip. Pleural field moderately and uniformly vaulted; 7 pleurae discernible, posterior pleural bands being higher and longer than anterior pleural bands, not reaching lateral edge; they terminate at slight break in slope that defines flat, lesser inclined, sharp-edged border region. Sculpture: densely granulose; postvincular doublure smooth.

Remarks. - ?Perliproetus münsteri Richter, 1869 from Saalfeld, Thuringia, based on pygidia alone, was recognised representing the pygidium of $N$. incisus, and as such constitutes a junior synonym of the latter (Feist \& Weyer 2018). New features of the ventral side of the cephalon, notably the vincular structure, only known from immature specimens (Crônier 2007), are described, and further traits 
of the pygidium are added to the original description provided by Richter \& Richter (1926, p. 151).

\section{Nephranops (Nephranops) aff. incisus (Roemer, 1866) Figure 4V, W}

Material. - Pygidium UM-IP 820 from locality BouOunebdou, $5 \mathrm{~km}$ SE of Mrirt, Central Moroccan Meseta, from first $20 \mathrm{~cm}$ above Upper Kellwasser Horizon, Middle triangularis Zone (after Lazreq 1992).

Remarks. - The single specimen shares with incisus the general outline of the pygidium with sharp posterolateral edges, and the long, narrow axis with a post-axial crestlike prolongation that does not reach the posterior edge. In contrast, anterior and posterior pleural bands are almost equal in height and length. In lateral view the profile of the axis is straight, without median depression. Further material is necessary to assess the assignment of the specimen. This is the first evidence of Nephranops in North Africa.

\section{Nephranops (Nephranops) angerae sp. nov. Figure 4M-R}

Holotype. - Cephalon, UM-IP 821, Fig. 4M-O, from Coumiac, Montagne Noire, Middle triangularis Zone.

Type horizon and locality. - Coumiac marble quarry, near Cessenon, Hérault, S France; upper quarry, bed 32c, hematite-rich, dark red calcilutite (Klapper et al. 1993).

Material. - Paratypes: 2 cephala UM-IP 822, 823 from type horizon.

Etymology. - After Jana Anger, Senckenberg Museum Frankfurt, in recognition of her assistance and help.

Diagnosis. - Cephalon semicircular with glabella in front of intercalating ring wide, covering anterior border, laterally defined by slightly sigmoidal axial furrows; narrow intercalating ring with backwards protruding lateral lobes; junction between posterior and lateral border furrows blunt; sculpture: dense tuberculation of elongated fused nodules forming wavy alignments.
Description. - Cephalon of semicircular outline anterolaterally. Genal field of half glabellar width, slightly truncated in anterior outline, covering anterior border. Axial furrow deep, slightly sigmoidal between S1 and lateral corners of frontal lobe. Lateral glabellar furrows rather deeply impressed, S2 small triangular, posterior branch of S3 crescent-shaped. Glabellar furrow S1 straight, becoming very shallow medially. Intercalating ring straight, narrow, inflated medially with less inflated, low lateral lobes, anteriorly separated from median lobe by deep notches connected with S1, extending rearwards beyond median portion of occipital furrow. Occipital ring more than twice as long (sag.) as intercalating ring, sub-rectangular, higher than glabella in front of intercalating ring, evenly vaulted, abruptly narrowing distally behind lateral lobes of intercalating ring. Genal field sub-triangular, posterior and lateral border furrows very shallow, merging in an obtuse angle. Palpebral lobe an oblique, low swelling differentiated from posterior genal field by indistinct palpebral furrow. Visual surface slightly swollen, without lenses, sharply differentiated from palpebral lobe by markedly incised facial suture. Antero-lateral margins sharp-edged, carrying a thin rim. Anterior border discrete, not protruding, remaining below anterior glabellar lobe, and slightly upturned on its anterior side. Vincular furrow very shallow, almost imperceptible medially, merging with postvincular doublure, becoming conspicuous abaxially in the form of a narrow, un-notched groove below lateral border. Sculpture: dense elongated nodules tending to form alignments of fused nodules across glabella that curve backwards abaxially. Vincular doublure with dense, wavy lines of fused elongated tubercles; distal vincular furrows smooth.

Remarks. - The new species differs from Nephranops (Nephranops) dillanus in its anteriorly wider glabella that covers the anterior border, the backwardly extending lateral lobes of the intercalating ring, and the typically wavy alignments of nodules on the entire cephalon.

\section{Subgenus Nephranops (Maternia) subgen. nov.}

Type species. - Nephranops incisus dillanus Richter \& Richter, 1926.

Etymology. - After Hans Matern who investigated the

Figure 4. A-L, S-U - Nephranops (Nephranops) incisus (Roemer, 1866), Sessacker near Oberscheld, Eastern Rhenish Slate Mountains, Germany; A-C - cephalon SMF X565a, latex cast of original specimen figured by Richter \& Richter (1926, pl. 9, fig. 49), dorsal (A), lateral (B), anterior (C) views; D, E - cephalon SMF 97026, almost entirely exfoliated, dorsal (D), oblique antero-lateral (E) views; F-H - pygidium SMF 97027, dorsal (F), posterior (G), lateral (H) views; I, J - cephalon SMF 97028, dorsal (I), lateral (J) views; K, L - fragment of anterior cephalon SMF 97030 showing ventral doublure, antero-lateral (K), ventral (L) views; S-U - pygidium SMF 97029, posterior (S), lateral (T), dorsal (U) views. • M-R - Nephranops (Nephranops) angerae sp. nov., Coumiac, Montagne Noire, Southern France; M-O - holotype cephalon UM-IP 821, anterior (M), lateral (N), dorsal (O) views; P, Q - cephalon UM-IP 822 partially exfoliated, ventral (P), dorsal (Q) views; R - cephalon UM-IP 823, dorsal view. • V, W - Nephranops (Nephranops) aff. incisus, M'rirt, Central hercynian Meseta, Morocco. Pygidium UM-IP 820 dorsal (V), lateral (W) views. Scale $=1 \mathrm{~mm}$. 


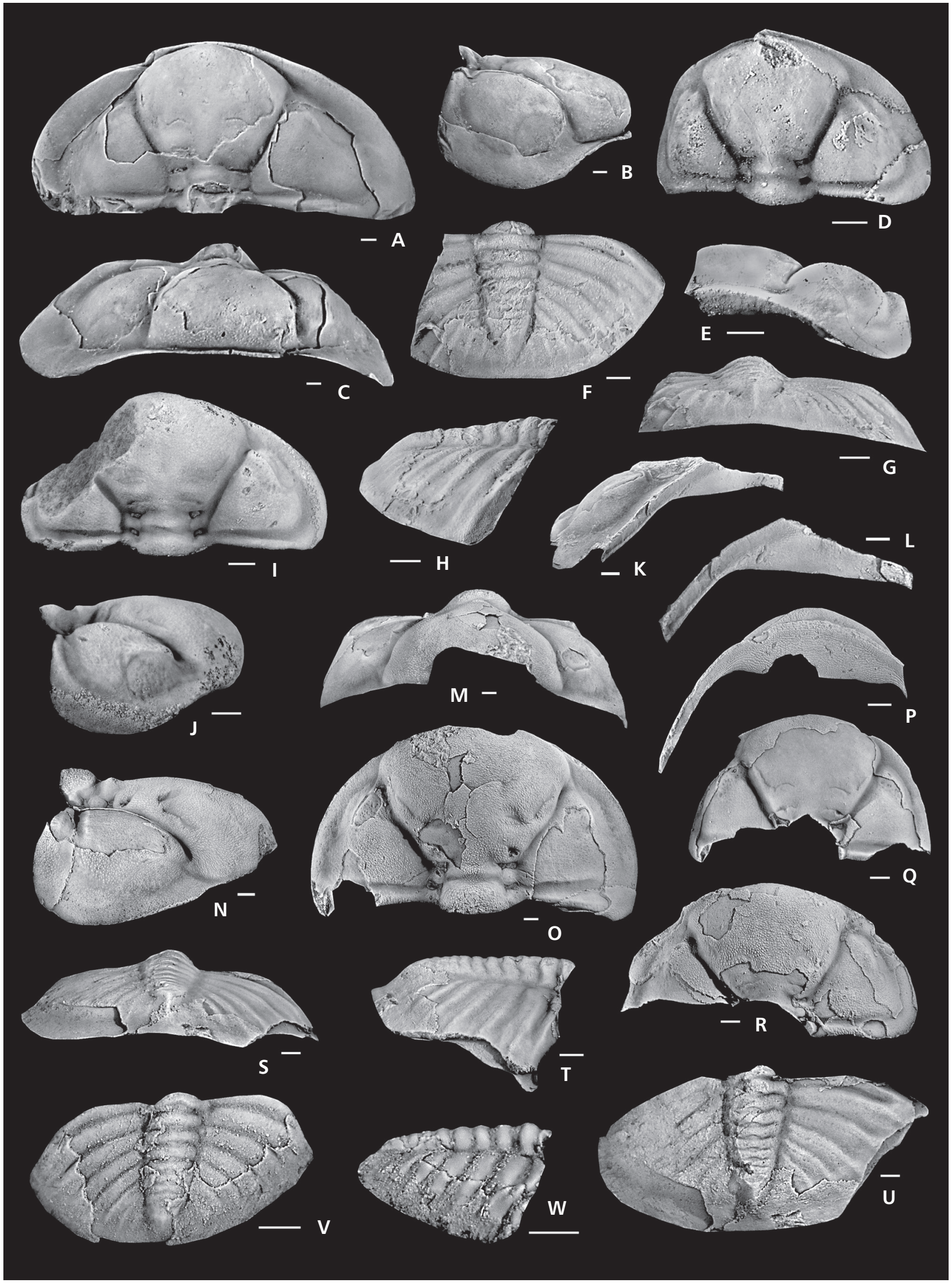


Late Devonian faunas of the Dill region and especially trilobites from several trenched sections at Sessacker near Oberscheld.

Diagnosis. - Antero-lateral borders of cephalon slightly vaulted with blunt edges; inflated anterior border, anteriorly pitted; vincular furrow rather deep, with well defined posterior edge of same height as anterior edge in lateral view; long postvincular doublure, anteriorly flat, concave behind with backwards convex hypostomal suture; pygidium more than twice as wide as long, axis obtusely rounded behind with 8-9 rings and short terminal piece, post-axial region very short, deeply inclined; pleural region with 5-6 ribs, equal in height and length; pleural furrows rather deep remaining distant from pygidial margins, postero-lateral margin slightly downturned, blunt, edge with marginal rim. Sculpture: dense nodules.

Occurrence. - Rhenish Slate Mountains, Harz, Montagne Noire; Middle triangularis through Early crepida zones.

Species included. - N. (Maternia) dillanus Richter \& Richter, 1926, Rhenish Slate Mountains, Harz Mountains; N. (M.) franconicus Alberti, 1970, Franconia; N. (M.) occitanicus sp. nov.

\section{Nephranops (Maternia) dillanus Richter \& Richter, 1926}

Figures 3C; 5J-Q

*v 1926 Phacops (Nephranops) incisus dillanus; Richter \& Richter, p. 180, pl. 10, figs 76-79.

non 1927 Phacops (Nephranops) incisus dillanus. - Matern, p. 255, [= Pulvinocephalus (Pulvinocephalus) steinachensis triangulus subsp. nov.].

2009 Nephranops dillanus. - Feist et al., p. 14.

Material. - Holotype cephalon, SMF RX 566b figured by Richter \& Richter (1926), pl. 9, fig. 51, refigured herein; cephalon, SMF X 566h, Matern (1927), Sessacker trench 2, bed 7, Early crepida Zone; new material from Sessacker, coll. Lippert in Ziegler (1962): 2 cephala, SMF 97032, SMF 97033, trench I, bed 20, 1 pygidium, SMF 97031 trench II, bed 23, Late triangularis Z.; cephalon NKMBT1017 from Sessacker; slab with dissociated sclerites of same specimen comprising cephalon, hypostome, thoracic segment and pygidium, Weilburg/Lahn, MB.T 8258.1.

Diagnosis. - Anterior outline of glabella widely elliptical; frontal glabellar lobe slightly overhanging medially without overhanging anterior border; hypostome with straight converging posterior edges, pointed behind; vincular furrow deep with wide parabolic curvature, slightly widening distally, postvincular doublure concave, three times longer than vincular furrow (sag.); thoracic axial rings with swollen lateral lobes; pygidium transverse, short, evenly curved behind, axis with narrow parabolic posterior outline, pleural region moderately vaulted with thin marginal rim present antero-laterally.

\section{Nephranops (Maternia) occitanicus sp. nov.} Figure 5A-I

non 1989 Nephranops incisus. - Becker et al., p. 262, fig. 3. non 1993 Nephranops dillanus. - Klapper et al., p. 483, fig. 7.

Holotype. - Cephalon, UM-IP 824, Fig. 5A-C, from Causses-et-Veyran, Montagne Noire, Middle triangularis Zone.

Type horizon and locality. - Causses-et-Veyran, Hérault, Southern France, $400 \mathrm{~m} \mathrm{~W}$ of village; CV-S section, bed 35 (Feist 1990, p. 25, fig. 11), hematite-rich, brick-red calcilutite.

Material. - Paratypes : 2 cephala UM-IP 825-826, from type horizon, 1 cephalon with residual lenses UM-IP 827 , from CV-S section, bed 33, cephalon UM-IP 828 from Coumiac UQ, bed 36 (Upper triangularis Zone, Feist 1990), 2 pygidia UM-IP 829-830, from type horizon.

Etymology. - From Occitania [Latin], Roman Province in Southern France.

Diagnosis. - Glabella highly vaulted, sub-pentagonal, pointed medially, overhanging frontal border; lateral glabellar furrows forwardly curved adaxially; intercalating ring with flat lateral lobes expanding forwards distally; postvincular doublure very long (sag.). Pygidium slightly truncated behind; axis high, weakly tapering; strong marginal rim at postero-lateral edges.

Figure 5. A-I-Nephranops (Maternia) occitanicus sp. nov., Causses-et-Veyran, Montagne Noire, Southern France; A-C-holotype cephalon UM-IP 824, dorsal (A), lateral (B), anterior (C) views; D, G - cephalon UM-IP 828, dorsal (D), ventral (G) views; E, H, I - pygidium UM-IP 829, lateral (E), dorsal (H), posterior (I) views; F - cephalon UM-IP 827, latex cast of internal mould, antero-lateral view showing visual surface with two residual lenses. - J-Q - Nephranops (Maternia) dillanus Richter \& Richter, 1926, Sessacker near Oberscheld (J-P), Weilburg/Lahn (Q), Eastern Rhenish Slate Mountains., Germany; J - holotype cephalon SMF-X566b, latex cast of original specimen, dorsal view; K, L, N - cephalon SMF -X566h, ventral (K), lateral (L), dorsal (N) views; M - pygidium SMF 97031, dorsal view; O, P - cephalon NKMB-T1017, dorsal (O), anterior (P) views; Q - dissociated sclerites of same individual on same slab MB. T 8258.1, cephalon (a), thoracic segment (b), pygidium (c), hypostome (d). Scale $=1 \mathrm{~mm}$. 


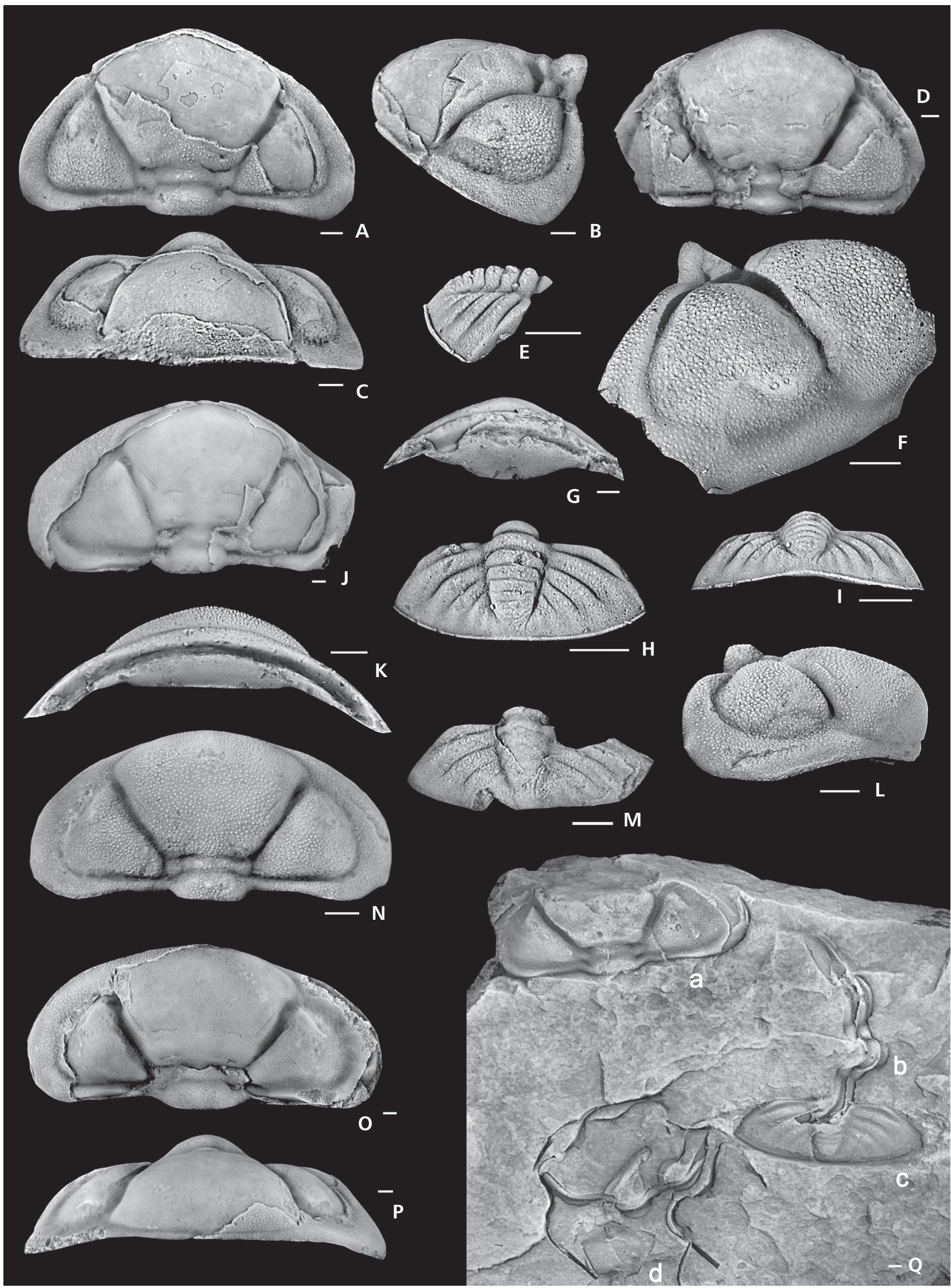


Description. - Cephalon almost twice as wide as long, of evenly curved anterior outline. Glabella sub-pentagonal, as long as wide, pointed anteriorly with obtusely angular antero-lateral corners, of high, continuously vaulted lateral and frontal profiles, overhanging anterior border adaxially. Axial furrows straight anteriorly, slightly outwardly curved behind. Lateral glabellar furrows markedly impressed. S1 narrow and deep distally, not reaching axial furrow, forwardly curved adaxially where merging with very shallow median portion. Intercalating ring straight, slightly vaulted in its median part (sag.) carrying two tubercles, with less vaulted sub-quadrangular lateral lobes that are projected forwards distally. Occipital ring strongly vaulted (sag., tr.), higher and wider (tr.) than base of glabella in front of L1, twice as long as intercalating ring (sag.), carrying flat, pitted median tubercle. Anterior border protruding from border furrow, moderately vaulted (sag.) medially, continuously narrowing distally until merging with slightly vaulted, sharply edged antero-lateral border. Vincular furrow deep, anteriorly merging with frontal slope of anterior border, as long as anterior border (sag.), well defined by sharp edge against very long (sag.) postvincular doublure, that is anteriorly flat and slightly downwardly curved posteriorly. Genal field strongly vaulted throughout, circumscribed by homogeneously deep border furrows. Eye lobe in advanced position, very low with slightly swollen oblique palpebral lobe. Visual surface is rather small, slightly sunken against palpebral lobe, well defined by crescent-shaped facial suture, generally without lenses with the exception of a single case, where two residual tiny lenses of different sizes seem to be developed (Fig. 5F). Sculpture: densely set nodules throughout including visual surface.

Early holaspid pygidium transverse sub-pentagonal with slightly truncated posterior outline, shorter (sag.) than half width (length/width index $=1: 2.4$ ), strongly curved lateral profile, kinked posterior border in posterior view. Axis is highly vaulted, weakly tapering, long with undefined posterior outline, not reaching posterior edge. Eight vaulted axial rings, markedly separated by straight ring furrows that reach axial furrows where slightly backwardly curved. Pleural region horizontal adaxially, strongly downwardly curved distally in posterior view, with 5 ribs markedly separated by deep pleural furrows that terminate far distant from postero-lateral margin. Interpleural furrows are inconspicuous. Strong marginal rim runs along antero-lateral edges. Sculpture: dense nodules becoming finer peripherally, outer margins smooth.

Remarks. - The new species shares with Nephranops (Maternia) dillanus the position and outline of the palpebral lobes and the small librigenae. It is distinct mainly in the markedly pointed anterior outline of the glabella, its higher transverse vault, the larger, anteriorly expanding lateral lobes of the intercalating ring and the much longer postvincular doublure. The pygidium is relatively longer and has a pronounced marginal rim. The new species shares the anteriorly protruding frontal glabellar lobe and the long postvincular doublure with $N$. (M.) franconicus. The main difference is seen in the shape of the palpebral lobe, which in franconicus extends significantly farther backwards, is more prominent and situated almost equidistant from the sagittal line anteriorly and posteriorly.

\section{Genus Pulvinocephalus gen. nov.}

Type species. - Phacops (Trimerocephalus) steinachensis Richter \& Richter, 1926.

Etymology. - pulvinus [Latin] $=$ cushion, referring to the cushion-like protruding anterior border of cephalon.

Diagnosis. - Reduced-eyed or blind with palpebral suture running onto cheek; anterior border cushion-like inflated, protruding beyond front of glabella, vincular furrow rather long (sag.) and shallow; pygidium transverse, axis high, narrow, almost reaching posterior edge.

Remarks. - The new genus regroups phacopine taxa with anterior cephalic border forwardly extending beyond anterior outline of glabella. The nominotypical subgenus is characterised by blind species whereas the new subgenus $P$. (Cryphopsides) comprises oculated species.

Occurrence. - Early Famennian: Early triangularis to Early marginifera zones.

Subgenera included. - P. (Pulvinocephalus) subgen. nov., P. (Cryphopsides) subgen. nov.

\section{Subgenus Pulvinocephalus (Pulvinocephalus) gen. et subgen. nov.}

Type species. - Phacops (Trimerocephalus) steinachensis Richter \& Richter, 1926.

Diagnosis. - Glabella low, with flat median profile, not overhanging anterior border furrow; anterior border inflated, protruding, widest opposite anterior axial furrows (exsag.), genal field without eyes, suture running onto cheek anteriorly; vincular furrow very shallow and long, with ill-defined posterior edge; postvincular doublure short, flat; pygidium transverse with evenly rounded posterior outline, narrow axis with 5 flat rings, inclined behind, merging with postaxial region; pleural field with 4 ribs not reaching margin. 
Occurrence. - Rhenish and Thuringian Slate Mountains, Harz Mountains, Germany; Early crepida to Early marginifera zones.

Species included. - Phacops (Trimerocephalus) steinachensis Richter \& Richter, 1926; Pulvinocephalus (Pulvinocephalus) steinachensis triangulus subsp. nov.; Pulvinocephalus sp. [= Phacops (Nephranops?) sp., Maximova (1955), p. 149, pl. 12, fig. 13].

\section{Pulvinocephalus (Pulvinocephalus) steinachensis (Richter \& Richter, 1926)}

Subspecies included. - P. (P.) steinachensis steinachensis (Richter \& Richter, 1926), P. (P.) steinachensis triangulus subsp. nov.

Pulvinocephalus (Pulvinocephalus) steinachensis steinachensis (Richter \& Richter, 1926)

Figure 6D-F, J, K, R, S

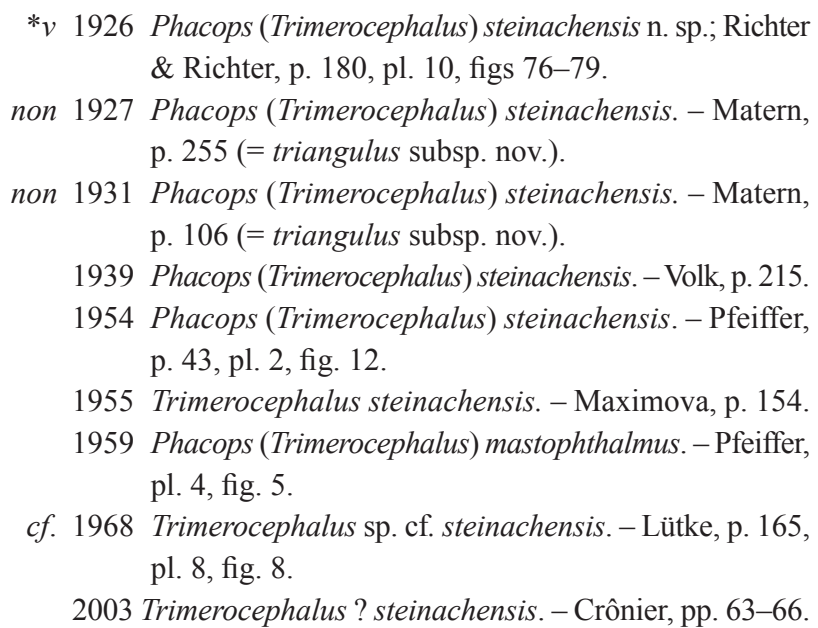

Material. - Cephalon SMF-X 540b figured by Richter \& Richter (1926, pl. 10, fig. 78), refigured herein; coll. Volk (1939) from type-locality Steinach, Thuringia: cephala SMF 540 h, 1, pygidium SMF-540 c; cephalon BGRB BD 2534/1, coll. Reuter, Bohlen section, Thuringia, Plattenbruch Member, bed 4, late early Famennian.

Diagnosis. - Cephalon with evenly rounded anterior outline. Maximum width of cephalon opposite two-thirds cephalic length (sag.) from anterior; with remnant eyeprotuberances crossed by facial suture; pygidium with axis having rounded posterior outline and relatively long postaxial region.

Remarks. - In addition to the description of Richter \& Richter (1926): the anterior axial furrows of the cephalon are deeply impressed slightly before reaching the border furrow. At this point the adaxial anterior cheek is markedly notched by the passage of facial suture that partly separates a minute swollen portion of anterior-most cheek. The entire exoskeleton is covered with tiny tubercles that become coarser on frontal parts of glabella and on anterior border. The hitherto un-described pygidium is elongated transversely. The axis has 5 slightly vaulted (sag.) rings, the first of which has a pseudo-articulating half-ring. First 2 interring furrows reaching axial furrows, very shallow medially, deepening abaxially and forming deep oval pits distally. Posterior rings fused medially and separated abaxially by thin inter-ring furrows that do not reach axial furrows.

Occurrence. - Thuringia; Harz Mountains (cf. steinachensis after Lütke 1968); Early marginifera Zone after Lütke (1968).

Pulvinocephalus (Pulvinocephalus) steinachensis triangulus subsp. nov.

Figures 3F; 6A-C, G, H

Holotype. - Cephalon SMF-X 540 d, coll. Matern, Sessacker trench II, bed 4, rhomboidea Zone, Fig. 6A-C.

Type horizon and locality. - Sessacker near Oberscheld, eastern Rhenish Slate Mountains, Germany; trench II, bed 4 of Matern (1927), red calcilutite with Palmatolepis cf. rhomboidea, Pa. quadrantinodosalobata, Icriodus alternatus alternatus: rhomboidea Zone.

Material. - Holotype specimen SMF-X 540 d; paratypes: pygidium SMF-X 566g, trench II, bed 4 of Matern (1927), pygidium SMF-X 540e, associated to poorly preserved cephalon, trench II bed 5 of Matern (1927), red calcilutite with $\mathrm{Pa}$. rhomboidea: rhomboidea Zone; 1 fragment of cephalon showing vincular furrow, SMF 97034, trench VI, 29 b, Early crepida Zone, after Schülke (1995).

Etymology. - After the triangular anterior outline of cephalon.

Diagnosis. - Outline of cephalon truncated anterolaterally, widest opposite to occipital furrow; anterior angle of cheek without protuberances; facial suture cutting small recessed crescent into anterior cheek; pygidial axis narrow anteriorly, with obtusely pointed posterior outline; postaxial region short.

Description. - The cephalon with a sub-cylindrical anterior border that is truncated antero-laterally, i.e. longer adaxially and in line with course of axial furrows; at the latter position it is markedly swollen, a little uplifted, and causes a slight backwards deflection of the border furrow. Crescent-shaped anteriormost portion of genal field between border furrow and suture is markedly lowered. Border furrow remains 
continuously deep around genal angles. Genal angles shifted far behind to a position opposite occipital furrow. In lateral view, profile of glabella flat-topped, strongly downcurved anteriorly, slightly overhanging anterior border furrow. Axial furrows straight and deep; anterior corners of glabella sub-angular, not extending outwards. Anterior outline of glabella is sub-circular. Pygidium transverse, length $/$ width ratio $=0.43$, posterior outline widely rounded; axis narrow, nearly half as wide as pleural region, with $5+1$ indistinct, low, straight rings, obtusely pointed behind, not reaching posterior edge. Pleural region slightly vaulted, more strongly at posterior margin, with 4 undivided ribs separated by relatively deep pleural furrows that die out far from lateral border. No border; edges with narrow rim. In lateral view, profile of axis evenly curved with very low axial rings, effaced behind, the posterior end merging with vaulted postaxial region. Sculpture: dense small-sized tuberculation throughout.

Remarks. - Differences from nominate subspecies: cephalon with triangular anterior outline, anterior outline of glabella sub-circular (elliptical in steinachensis) smaller area of genal field cut by suture, absence of ocular protuberences on anterior gena, border furrow continuously deep at genal angles (shallower in steinachensis), maximum width father behind. First axial ring in the pygidium as wide transversely as second (in steinachensis it is wider). Ring furrows shallow but continuous (in steinachensis only first one continuous, the following impressed only distally and effaced medially). Posterior end of axis obtusely pointed (in steinachensis vaguely rounded, largely merging with postaxial area, remaining more distant from posterior edge). Pleural ribs slightly vaulted (exsag.) (in steinachensis almost flat-topped).

Occurrence. - Type-locality only; Early crepida to rhomboidea zones.

\section{Subgenus Pulvinocephalus (Cryphopsides) gen. et sub- gen. nov.}

Type species. - P. (Cryphopsides) ovatus sp. nov.

Etymology. - Resembling Cryphops.
Diagnosis. - Anterior border of cephalon convex, very high (sag.); anterior outline of glabella wide, with obtusely rounded corners; axial furrows abaxially convex in front of S1; S2 and S3 indiscernable; genal field with ocular lobe bearing visual surface with lenses.

Remarks. - P. (Cr.) latilimbatus (Maximova, 1955) was recovered from the Barma horizon in the SW Uralian Bol'shaya Barma section with the brachiopod Pugnoides triaequalis Goss. [= Parapugnax markowskii (Yud.)]. Previously considered late Frasnian this horizon is now referred to the basal Famennian Early and Middle triangularis Zones by conodonts (Abramova \& Artyushkova 2004, Tagarieva 2013).

Occurrence. - Rhenish Slate Montians, Southern Urals; Early Famennian triangularis through crepida zones.

Species included. - P. (Cryphopsides) ovatus sp. nov., Late triangularis-Latest crepida Zones, Sessacker, Germany; P. (Cr.) latilimbatus (Maximova, 1955), Early and Middle triangularis zones, SW Urals; tentatively assigned: $P$. (?Cr.) walliseri sp. nov., Late crepida Zone, Sessacker, Germany.

\section{Pulvinocephalus (Cryphopsides) ovatus sp. nov.} Figure 6P

v 1927 Phacops (Cryphops) cryptophthalmus. - Matern, p. 255. 2000 Cryphops cf. latilimbatus. - Crônier \& Feist, p. 505, pl. 1, fig. 10a-d.

Holotype. - Cephalon SMF-X 563 b, Sessacker, coll. Matern, trench II, bed 5, figured in Crônier \& Feist (2000, pl. 1, fig. 10a-d).

Type horizon and locality. - Sessacker near Oberscheld, eastern Rhenish Slate Mountains, Germany; trench II, bed 5 of Matern (1927), red calcilutite with Palmatolepis quadrantinodosalobata, Icriodus alternatus alternatus: Latest crepida Zone.

Material. - Paratype: fragmentary cephalon SMF 97035 , Sessacker, coll. Lippert, trench II, bed 23, Late triangularis Zone.

Figure 6. A-C, G, H - Pulvinocephalus (Pulvinocephalus) steinachensis triangulus subsp. nov., Sessacker near Oberscheld, Eastern Rhenish Slate Mountains, Germany; A-C - holotype cephalon SMF-X540d, dorsal (A), lateral (B), anterior (C) views; G, H - pygidium SMF-X540e, dorsal (G), lateral (H) views. • D-F, J, K, R, S - Pulvinocephalus (Pulvinocephalus) steinachensis steinachensis (Richter \& Richter, 1926), Steinach, Thuringia; D-F - cephalon SMF-X540b, plaster cast of original specimen, lateral (D), anterior (E), dorsal (F) views; J, K, R, S - pygidium and cephalon SMF-X540c, latex casts of original specimens, posterior (J), dorsal $(\mathrm{K})$ views of pygidium, dorsal (R), lateral (S) views of cephalon. $\bullet$ I, L-O, Q, T, U - Pulvinocephalus (?Cryphopsides) walliseri ?subgen. et sp. nov., Sessacker near Oberscheld, Eastern Rhenish Slate Mountains, Germany; I, L-O holotype cephalon SMF 97036 ventral (I), antero-lateral (L, latex cast of internal mould), dorsal (M, latex cast of internal mould), anterior (N), dorsal (O) views; Q, T, U - cephalon SMF 97037, dorsal (Q), oblique antero-lateral (T), lateral (U) views. • P - Pulvinocephalus (Cryphopsides) ovatus subgen. and sp. nov., Sessacker near Oberscheld, Eastern Rhenish Slate Mountains, Germany, cephalon SMF 97035, lateral view. Scale = $1 \mathrm{~mm}$. 


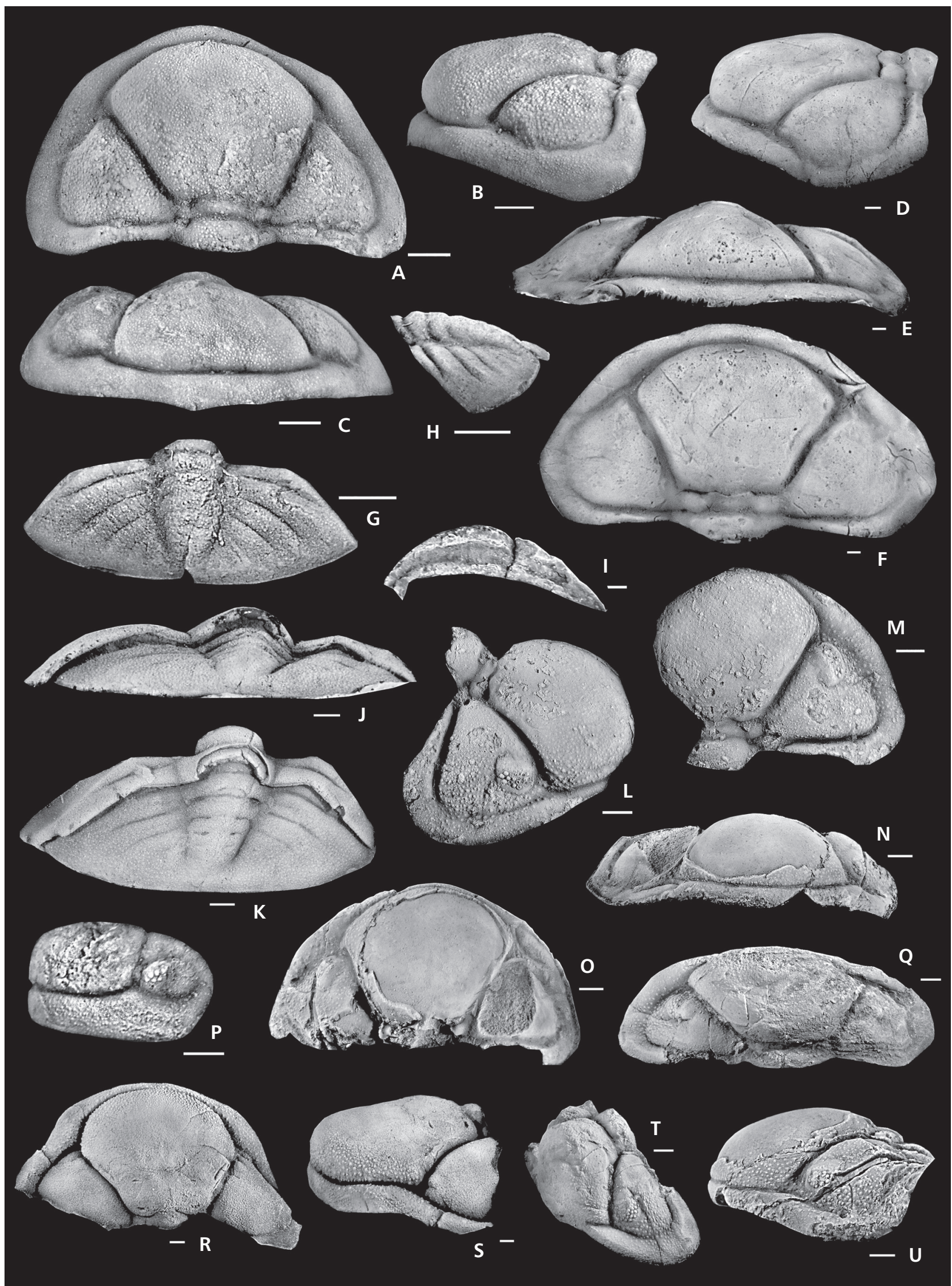


Etymology. - ovatus $[$ Latin] $=$ oval, referring to shape of visual surface.

Diagnosis. - Anterior border as high as front of glabella in anterior view; anterior outline of glabella widely parabolic; posterior axial furrows inwardly curved; eye lobes small, ovoid, situated far forward with lower edge in border furrow; palpebral furrows oblique, adaxially convex; visual surface oval, with 5-6 lenses; antero-lateral border enlarged at junction between axial and border furrows.

Description. - See Crônier \& Feist (2000, p. 505).

Remarks. - The new species differs from latilimbatus mainly in the form and position of the eye, which, in the latter, is kidney-shaped and extends farther to the rear.

Occurrence. - Rhenish Slate Mountains (Sessacker only); Late triangularis through latest crepida zones.

Pulvinocephalus (?Cryphopsides) walliseri sp. nov. Figures 3G; 6I, L-O, Q, T, U

Holotype. - Cephalon SMF 97036 Sessacker trench VI, Late crepida Zone, Fig. 3G; 6I, L-O.

Type horizon and locality. - Sessacker near Oberscheld, eastern Rhenish Slate Mts., Germany; Sessacker trench VI, red calcilutite, loose sample, Late crepida Zone.

Material. - Cephalon SMF 97037, Sessacker trench VI, same slab as holotype.

Etymology. - After the late Prof. O. Walliser who discovered the holotype specimen.

Diagnosis. - Frontal glabellar lobe low semi-circular, not overhanging anterior border of moderate height; axial furrows straight in front of $\mathrm{S} 1$; ocular lobe on anterior genal field, close to border furrow, with crescent-shaped, oblique palpebral lobes, straight palpebral furrows, kidney-shaped visual surface carrying numerous lenses; vincular furrow deep, postvincular doublure very short, swollen.

Description. - Anterior outline of glabella semi-circular, of even curvature and high transverse vault, moderately strongly vaulted in lateral view. Frontal glabellar lobe descends moderately steeply anteriorly, not overhanging border furrow. Anterior border is of moderate vertical height adaxially. Axial furrows straight in front of S1, meeting border furrow in an obtuse angle at glabella corners. Anterior genal field exhibits small elevated triangular area between facial suture and axial furrow adjacent to glabellar corners. Eye lobe situated far forward but remains distant from antero-lateral border furrow leaving an interval equivalent to half width of adjacent border. Palpebral lobes elongated crescent-shaped, flat, adaxially inclined, with abaxially convex palpebral suture and straight, obliquely diverging palpebral furrows. Visual surface is kidney-shaped with about 17 lenses. Vincular furrow is rather deep and wide (sag.), and sharply delimited against lower edge of anterior border and postvincular doublure. Postvincular doublure is rather short, markedly lower than anterior edge of vincular furrow, crest-like, swollen, and shorter than half length of vincular furrow. Sculpture: densely tuberculated, coarser nodules on anterior slope of glabella, genal fields including pre-ocular genal field, and antero-lateral borders.

Remarks. - The configuration of the vincular structure resembles Cryphops cryptophthalmus (Emmrich, 1844) in the deep position of the posterior edge of the vincular furrow and the reduction of the postvincular doublure. However, in contrast to crypthophthalmus where the vincular furrow terminates posteriorly with a sharp edge without postvincular doublure, in the new species there is a marked swollen rim representing an enrolled, rather short postvincular doublure. The main differences from Cryphops include the slightly forwardly protruding anterior border (compare Figs 3G and 6I) and the eye remaining distant from border and exhibiting kidney-shaped visual surfaces.

\section{Genus Cryphops Richter \& Richter, 1926}

Type species. - Phacops cryptophthalmus Emmrich, 1844.

Diagnosis. - See Crônier \& Feist (2000).

Remarks. - Phacops (Cryphops) latilimbatus Maximova, 1955 and Cryphops cf. latilimbatus Maximova, 1955 (in Crônier \& Feist 2000) are reassigned to Pulvinocephalus (Cryphopsides).

Species included. - Type species only.

Cryphops cryptophthalmus (Emmrich, 1844) Figures 3I; 7A-H

Synonymy. - See Crônier \& Feist (2000).

Material. - New material from Sessacker: cephalon SMF 97038, trench II R, collected Matern, latest crepida Zone; cephalon SMF 97039, collected Lippert, trench I, bed 25-26, Middle crepida Zone; pygidium SMF 97040, trench II R, collected Matern, on same slab as cephalon SMF 97038.

Diagnosis. - Glabella in front of L1 pentagonal with 
medially acute, anteriorly protruding anterior outline, antero-lateral border wide, moderately inflated, slightly kinked opposite axial furrows, ovoid eye-lobe on anteriormost genal field reaching border furrow, with elliptical visual surface carrying 7-11 lenses. Pre-vincular doublure very broad (sag.), slightly vaulted, inclined posteroventrally; vincular furrow deep, long (sag.), bordered by sharp edges, postvincular doublure absent. Pygidium transverse with narrow, long axis containing $7+1$ rings, pleural region with 5 ribs.

Remarks. - The hitherto un-recognized pygidium has the following characteristic traits: Pygidium transverse, length $/$ width ratio $=0.54$; axis robust, high, with continuously down-curved profile, with $7+1$ narrow, straight rings, separated by deep inter-ring-furrows; axial furrows weakly and uniformly converging backwards, posterior end of axis obtusely rounded, almost reaching posterior edge, merging with elevated post-axial region. Pleural region moderately vaulted, with 5 ribs whose anterior bands are longer than posterior ones but do not reach lateral edges. Latero-posterior margin has no border furrow, edge with tiny elevated rim.

\section{Genus Trifoliops Crônier, 2003}

Type species. - Dianops? trifolius Osmólska, 1958.

Diagnosis. - See Crônier (2003).

Remarks. - The species nigritus originally included by Crônier (2003) exhibits different diagnostic features including the short and wide glabella, the protruding anterior cephalic outline and relatively short (sag.) vincular furrow. It is excluded from Trifoliops here and assigned to Trimerocephalus with question.

Species included. - Dianops? trifolius Osmólska, 1958, Holy Cross Mountains., SW Algeria, Early rhomboidea Zone; T. cronierae Feist, 2016 in Feist et al. (2016), Marhouma, SW Algeria, Early rhomboidea Z.; T. septimanicus sp. nov., Causses-et-Veyran, Montagne Noire, Southern France, Late rhomboidea Zone.

\section{Trifoliops septimanicus sp. nov.}

Figures 3H, 7I-M

2003 Trimerocephalus (Trifoliops) trifolius. - Crônier, pp. 58, 59, figs $2 \mathrm{a}-\mathrm{d}, 3 \mathrm{a}, 4 \mathrm{a}, \mathrm{b}$.

2003 Trimerocephalus (Trifoliops) nigritus. - Crônier, pp. 59-62, fig. 6g, h.

2013 Trimerocephalus (Trifoliops) trifolius. - Crônier et al., p. 1012.

2016 Trifoliops trifolius. - Feist et al., p. 254.
Holotype. - Cephalon USTL/CC014 in Crônier (2003, fig. 2a), from Causses-et-Veyran, Southern France.

Type horizon and locality. - Causses-et-Veyran Village, Hérault, Southern France, Concours-le-Haut quarry; red nodular calcilutites with marly interstices, Bed 43 (in Girard et al. 2014, fig. 5), Late rhomboidea Zone.

Material. - Collection Crônier 2003 (USTL/CC014-017, 024-025), new material: 3 cephala UM-IP 831-833.

Etymology. - After Septimania [Latin], province of Southern France (Languedoc region).

Diagnosis. - Glabella slightly longer than wide, anterolateral border furrows straight; anterior cheek with ocular protuberances cut by facial suture; vincular furrow more than twice as long as postvincular doublure, widest medially, with continuously curved anterior and posterior edges, the anterior more highly arched than the posterior in ventral view; pygidium trapezoidal with framed pleural fields, and granulated, rather long vertical portion (sag.) of doublure.

Description. - Pygidium transverse trapezoidal with 4 axial rings. Terminal piece triangular with elevated sagittal ridge and lower abaxial parts; articulating half-ring longer than first axial ring, very long pseudo-articulating half-ring in front of second axial ring, bearing tubercles on it's posterior part, pseudo-articulating half-rings developed on third and fourth axial rings; axial rings inflated abaxially where flexed forward and separated by rather deep, transversely elongated muscle scars, axial rings moderately inflated medially. Post-axial region is half as long as terminal piece of axis. Four pleural ribs not extending to postero-lateral edges. Pleural fields are framed by thick, elevated marginal rim merging, on its external side, with vertical portion of doublure. Pleural furrows are deeper but shorter than interpleural furrows. Profile of axis evenly curved, pleural fields modestly vaulted. Sculpture: dense granules except on distal parts of pleural region which are smooth.

Comparison: The anterior border protrudes slightly beyond the anterior glabellar lobe, whereas it does not protrude in trifolius (cf. Osmólska 1963, pl. 4, fig.1). In the latter, the anterior edge of the vincular furrow is straight transversely, and both the vincular furrow and the postvincular doublure are less strongly curved than in septimanicus. The pygidium of the new species is closest to T. cronieri Feist, 2016 (see comparisons in Feist et al. 2016, p. 254).

Remarks. - The new species from the Montagne Noire was earlier assigned to Trimerocephalus (Trifoliops) trifolius (Osmólska, 1958) by Crônier 2003. Feist in Feist 
et al. (2016, p. 254) pointed out that the Montagne Noire material exhibits diagnostic features such as the presence of ocular protuberances that are absent in the Polish originals. Other distinct diagnostic characters, the outline of the vincular structure in particular, justify the specific differentiation of the Montagne Noire material. The pygidium was originally assigned to ?Trimerocephalus nigritus Crônier, 2003 before being reassigned by Crônier et al. (2013) to Trimerocephalus (Trifoliops) trifolius (Osmólska, 1958). It is here considered to belong to the new species Trifoliops septimanicus. A few morphological features are added to Crônier's description.

\section{Genus Trimerocephalus McCoy, 1849}

Type species. - Trinucleus? laevis Münster, $1842=$ Phacops (Trimerocephalus) mastophthalmus Reinhard Richter, 1856, Gattendorf, Thuringian Slate Mountains, Germany, early Famennian.

\section{?Trimerocephalus nigritus Crônier, 2003}

Figure $7 \mathrm{~N}-\mathrm{R}$

v. 2003 Trimerocephalus (Trifoliops) nigritus n. sp.; Crônier, pp. 59-62, figs 3b, 6a-f.

non 2003 Trimerocephalus (Trifoliops) nigritus; Crônier, pp. 59-62, fig. 6g, h.

2013 Trimerocephalus (Trifoliops) nigritus. - Crônier et al., pp. 10, 11, fig. $3 \mathrm{~d}-\mathrm{h}, \mathrm{s}-\mathrm{v}$.

2016 Trifoliops nigritus. - Feist et al., p. 253.

Material. - Collection Crônier 2003 (USTL/CC018-023); new material: 2 cephala UM-IP 834, 835; 1 pygidium UM-IP 836.

Diagnosis. - Glabella wider than long, overhanging anterior border furrow, antero-lateral border compressed, incurved, elevated opposite axial furrow; vincular furrow deep, shorter than postvincular doublure; pygidium transverse, lens-shaped; axis low with wide posterior end not reaching margin, four uniformly forwardly arched rings and continuous inter-ring furrows.
Description. - Features of the cranidium were described in detail by Crônier (2003). The newly discovered pygidium is lens-shaped. It has a wide, moderately vaulted axis with $4+1$ forwardly curved rings of even length (sag. exsag.) from the middle to their distal ends. Inter-ring furrows are well marked, deepening abaxially where reaching axial furrows. Posterior end of axis widely rounded, low, not reaching posterior margin. Pleural field moderately vaulted, with 4 ribs; pleural furrows as wide (tr.) as interpleural furrows but deeper than them; both vanishing far before reaching postero-lateral margin.

Remarks. - The species was hitherto assigned to Trifoliops on account of the inwardly curved antero-lateral cephalic borders that characterise T. trifolius and allies. In the latter the inward curvature results from the sudden increase in width (exsag.) and forward projection of the swollen border in front of the junction between antero-lateral border furrow and axial furrow. In antero-lateral view the border remains at the same level at this point and the anterolateral border furrow is straight. In nigritus the inward curvature results from the antero-lateral compression of the border which is elevated to a triangular, narrow structure surrounding the corners of the anterior glabella lobe (Fig. $7 \mathrm{~N})$. Unlike Trifoliops and Trimerocephalus, the ventral edge of the anterior border has a forwardly protruding rim. This rim extends abaxially along the antero-lateral border where it defines an elongated depression in the vertical outer slope of the border, which is upraised opposite the axial furrow (see arrow in Fig. $7 \mathrm{~N}$ ).

\section{Genus Struveops Crônier \& Feist, 2000}

Type species. - Phacops (Cryphops) schlosseri Richter \& Richter, 1955.

Diagnosis. - Cephalon eyeless, with functional marginal sutures; triangular, swollen palpebral lobe on border, separated from genal field by continuous border furrow reaching axial furrow far behind point of maximum lateral extension of glabella; pre-vincular doublure high, crescent-shaped, backward oriented; vincular furrow with

Figure 7. A-H - Cryphops cryptophthalmus (Emmrich, 1844), Sessacker near Oberscheld, Eastern Rhenish Slate Mountains, Germany; A-C cephalon SMF 97038, dorsal (A), antero-ventral (B), anterior (C) views; D, E - cephalon SMF 97039, lateral (D), dorsal (E) views; F-H - pygidium SMF 97040, lateral (F), dorsal (G), posterior (H) views. $\bullet$ I-M - Trifoliops septimanicus sp. nov., Concours-le-Haut near Causses-et-Veyran, Montagne Noire, Southern France; I, K, L - cephalon UM-IP 831, ventral (I), dorsal (K), lateral (M) views; J, M - cephalon UM-IP 832, dorsal (J), lateral (M) views. • N-R - ?Trimerocephalus nigritus Crônier, 2003, Concours-le-Haut near Causses-et-Veyran, Montagne Noire, Southern France; N, O, Q, $\mathrm{R}$ - cephalon UM-IP 834, oblique antero-lateral view (N) showing elevated antero-lateral border exhibiting longitudinal depression and marginal rim (arrow), lateral (O), dorsal (Q), ventral (R) views; P - pygidium UM-IP 836, dorsal view. $\bullet \mathrm{S}-\mathrm{Z}$ - Struveops wiedaensis sp. nov., Sessacker near Oberscheld, Rhenish Slate Mountains (S-T) and Stöberhaifahrweg near Wieda, Harz (U-Z), Germany; S - fragment of cranidium SMF 97055 , dorsal view; T - cranidium SMF 97056, dorsal view; U - cranidium SMF 97043, oblique antero-lateral view; V - cephalic doublure showing vincular furrow SMF 97044, ventral view; W - cranidium SMF 97042, dorsal view; X - pygidium SMF 97045, dorsal view; Y - pygidium SMF 97046, dorsal (Y1), lateral (Y2) views; $\mathrm{Z}$ - holotype cranidium SMF 97041, dorsal view. Scale $=1 \mathrm{~mm}$. 


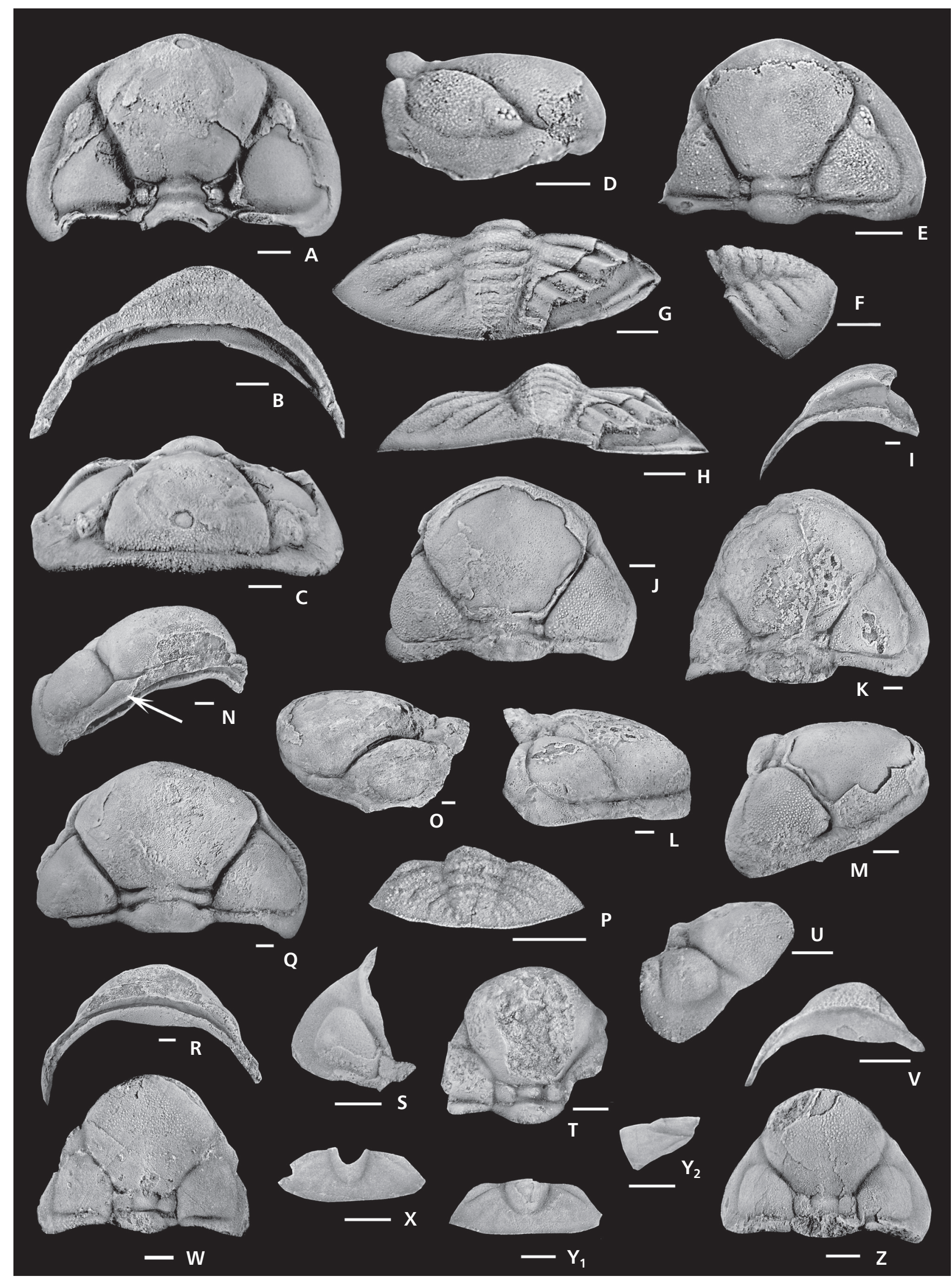


sharp anterior edge, devoid of posterior edge, merging with postvincular area of doublure; pygidium transverse with slightly truncated posterior edge; axis short and plump, furrows of axial rings and pleural fields almost effaced.

Species included. - Phacops (Cryphops) schlosseri Richter \& Richter, 1955 from Talnitz near Plauen, do III, Phacops (Trimerocephalus) pulvinifer Matern, 1927 from Sessacker, do III; Struveops wiedaensis sp. nov. from Stöberhaifahrweg near Wieda, Early marginifera Zone.

\section{Struveops wiedaensis sp. nov.}

Figures 3E, 7S-Z

1968 Cryphops schlosseri. - Lütke, p. 161, pl. 8, fig. 2a, b. p 2000 Struveops schlosseri. - Crônier \& Feist, pp. 509, 510, pl. 2, figs $13-17$, non 18 .

Holotype. - Cranidium SMF 97041, Fig. 7Z, Wieda, Harz Mountains, Early marginifera Zone.

Type horizon and locality. - Stöberhaifahrweg, north of Wieda, Harz Mountains; section Stöberhaifahrweg, bed 9 (Lütke 1968, fig. 3), Early marginifera Zone.

Material. - Paratypes: fragmentary cranidium SMF 97042, cranidium SMF 97043, cephalic doublure showing vincular furrow, SMF 97044, pygidia SMF 97045-46; additional material: 2 cranidia SMF 97047-48, 5 cephalic doublures SMF 97049-53, 1 fragmentary pygidium SMF 97054, all from type locality and horizon; coll. Lütke (SMF 20561b, 20568a-h); coll. Crônier \& Feist (SMF 57520-57524) from Wieda; fragmentary cranidia SMF 97055-56, Sessacker near Oberscheld, section Lippert SI 13, Early marginifera Zone.

Etymology. - After Wieda Township in the Harz Mountains.

Diagnosis. - Contour of cranidium parabolic with semicircular anterior outline of glabella, glabella in front of L1 shorter than wide, outer genal field and lateral border moderately sloping and not inflated, lateral border furrow evenly curved inward where merging with palpebral furrow, lateral lobes of intercalating ring markedly separated from median lobe by continuous longitudinal furrows.

Description. - Glabella in front of L1 wider than long (length/width ratio $=0.84$ ), inconspicuously truncated antero-laterally, evenly curved anteriorly, of moderate longitudinal and transverse vault, flattened behind, without discernible S2 and S3. Intercalating ring tripartite, with un-inflated quadrangular lateral lobes, longer and lower than swollen median lobe (exsag.) and separated from the latter by continuous ex-sagittal furrows, running from
$\mathrm{S} 1$ to occipital furrow. S1 is deeper in front of lateral occipital lobes, shallowing medially. Occipital furrow is continuously deep. Occipital ring, as high as median lobe of intercalating ring, extends forward medially to become slightly longer than intercalating ring (sag.); it is markedly reduced in length laterally, provided with tiny, inconspicuously separated lateral lobes. Genae as wide as occipital ring (tr.), moderately vaulted adaxially, flattened and modestly sloping abaxially. Genal field short (exsag.), sub-pentagonal, defined by uniformly deep border furrow that turns inwards anteriorly in a parabolic curve to merge with palpebral furrow, and to meet axial furrow in an acute angle. This junction lies in the posterior third of glabella in front of L1. Lateral border scarcely vaulted (tr.), moderately inclined, very wide at genal angle, narrowing forward, expanded anteriorly to form a triangular, inflated palpebral area. Extremely narrow strip devoid of visual surface remains beyond suture. Functional suture runs sub-marginally along genae before meeting anterior glabella lobe just in front of its maximum width (tr.). Frontal portion of suture separates a vaulted, sigmoidal pre-vincular doublure below remainder of frontal glabella that, in anterior view, is almost as high as the latter. The pre-vincular doublure is backwardly inclined, and sharply bordered by semi-circular anterior edge of vincular furrow. The latter is deep with steep anterior slope and a gently concave posterior area lacking a distinct edge and merging with flat postvincular doublure. Vincular furrows become narrow below genae in the form of marked groves devoid of pits. The dorsal exoskeleton provided with sculpture of dense, minute tuberculation throughout; the anterior half of glabella in front of L1 exhibits coarser tubercles. Pygidium transverse, short trapezoidal, with posterior outline widely curved, slightly truncated medially; axis rather short, a little longer than half length of pygidium (sag.), surrounded by continuous axial furrows, of parabolic posterior outline, high in lateral view, moderately inclined at posterior end, with 3 almost effaced axial rings of which the anterior-most is higher and medially narrower (sag.) than the others; pleural region modestly vaulted, with almost effaced 2-3 ribs, first pleural furrow well marked. Pygidium without sculpture except top of axial rings which display tiny tubercles.

Remarks. - The material from Wieda is very close to the younger Struveops schlosseri (do III from Plauen, Thuringia), to which it has hitherto been assigned. The main difference characterizing the new species is the markedly rounded anterior outline of the glabella which is therefore relatively shorter. The triangular palpebral area extends farther backward at the expense of the length of the genal field (exsag.); the maximum length of the palpebral area to the length of the genal field is 0.67 versus 0.43 in schlosseri. The intercalating ring of wiedaensis 
has a more prominent median lobe and the separation of the lateral lobes is strongly marked.

Struveops pulvinifer (do III from Sessacker, Oberscheld, Rhenish Slate Mountains.) shares with the new species the rounded anterior outline of the glabella, but the genal fields are much more strongly vaulted and, in anterior view, the genal fields and lateral borders exhibit a marked break in slope whereas they are evenly sloping in wiedaensis.

\section{Acknowledgements}

I am very grateful to Jana Anger and Eberhard Schindler (Frankfurt) for their help in providing casts and originals from the collections of the Senckenberg Museum, to Dieter Weyer (Berlin) and Carsten Brauckmann (Clausthal) for advice and discussions on systematics, stratigraphy and relevant literature, to Gilbert Klapper, Carlo Corradini and Catherine Girard for expert determination of conodont specimens. The thorough examination and constructive remarks of the two reviewers, David J. Holloway and Allart van Viersen, and of the editor Zuzana Tasáryová are deeply acknowledged. This is a contribution of UMR 5554, CNRS, Montpellier (ISEM 2019 - 017)

\section{References}

Abramova, A.N. \& Artyushrova O.V. 2004. The FrasnianFamennian boundary in the southern Urals. Geological Quarterly 48(3), 217-132.

Alberti, G.K.B. 1970. Zur Augenreduktion bei devonischen Trilobiten mit Beschreibung von Nephranops franconicus $\mathrm{n}$. sp. aus dem Oberdevon I $\alpha$ von Oberfranken. Paläontologische Zeitschrift 44(3-4), 145-160. DOI 10.1007/BF02990634

Basse, M. \& Müller, P. 2000. Illaenula struvei n. sp. aus Wissenbach-Schiefern der Dill-Mulde. Senckenbergiana lethaea 79, 441-457.

Becker, R.T., Feist, R., Flajs, G., House, M.R. \& Klapper, G. 1989. Frasnian-Famennian extinction events in the Devonian at Coumiac, southern France. Comptes Rendus de l'Académie des Sciences Paris 309 II, 259-266.

Chlupáč́, I. 1975. The distribution of phacopid trilobites in space and time. Fossils and Strata 4, 399-408.

Chlupéč, I. 1977. The phacopid trilobites of the Silurian and Devonian of Czechoslovakia. Rozpravy Ústředního ústavu geologického 43, 1-172.

CRônier, C. 2003. Systematic relationships of the blind phacopine trilobite Trimerocephalus, with a new species from Causses-et-Veyran, Montagne Noire. Acta Palaeontologica Polonica 48(1), 55-70.

CRÔNIER, C. 2007. Larval morphology and ontogeny of an Upper Devonian phacopid: Nephranops from Thuringia, Germany. Journal of Paleontology 81(4), 684-700. DOI 10.1666/ pleo0022-3360(2007)081[0684:LMAOOA]2.0.CO;2

Crônier, C. \& Feist, R. 2000. Evolution et systématique du groupe Cryphops (Trilobita, Phacopinae) du Dévonien supérieur. Senckenbergiana lethaea 79, 501-515.

Crônier, C. \& François, A. 2014. Distribution patterns of Upper Devonian phacopid trilobites: paleobiogeographical and paleoenvironmental significance. Palaeogeography, Palaeoclimatology, Palaeoecology 404, 12-23.

DOI 10.1016/j.palaeo.2014.03.037

Crônier, C., Malti, F.Z., François, A., Benyoucef, M. \& Brice, D. 2013. First occurrence of a phacopid trilobite faunule from the Upper Devonian of Saoura Valley, Algeria and biodiversity fluctuations. Geological Magazine 150(6), 1002-1021. DOI 10.1017/S0016756813000277

Drevermann, F. 1901. Die Fauna der oberdevonischen Tuffbreccie von Langenaubach bei Haiger. Jahrbuch der Preußischen Geologischen Landesanstalt for 1900, 99-207.

Emmrich, H.F. 1844. Zur Naturgeschichte der Trilobiten. Programm Realschule Meiningen, 1-28.

FeIst, R. (ed.) 1990. The Frasnian/Famennian boundary and adjacent strata of the eastern Montagne Noire, France. 69 pp. IUGS Guide book, Subcommission of Devonian Stratigraphy, Montpellier.

FeIst, R. 1991. The Late Devonian trilobite crises. Historical Biology 5, 197-214. DOI 10.1080/10292389109380401

FeIst, R. 1995. Effect of paedomorphosis in eye reduction on patterns of evolution and extinction in Trilobites, 225244. In McNamara, K.J. (ed.) Evolutionary Change and Heterochrony. Wiley, Chichester.

Feist, R. \& Becker, R.T. 1997. Discovery of Famennian trilobites in Australia (Late Devonian, Canning Basin, NW Australia). Geobios (Mémoire special 20), 231-242.

Feist, R. \& Schindler, E. 1994. Trilobites during the Frasnian Kellwasser Crisis in European Late Devonian cephalopod limestones. Courier Forschungsinstitut Senckenberg 169, 195-223.

Feist, R. \& Weyer, D. 2018. The proetid trilobite Perliproetus, a marker of the late Famennian in Central Europe and North Africa. Neues Jahrbuch für Geologie und Paläontologie, Abhandlungen 287(2), 195-206. DOI 10.1127/njgpa/2018/0712

Feist, R., Mahboubi, A. \& Girard, C. 2016. New Late Devonian phacopid trilobites from Marhouma, SW Algerian Sahara. Bulletin of Geosciences 91(2), 243-259.

DOI 10.3140/bull.geosci.1600

Feist, R., Yasdi, M. \& Becker, R.T. 2003. Famennian trilobites from the Shotori Range, E - Iran. Annales de la Société Géologique du Nord 10, 285-295.

Feist, R., McNamara, K.J., Crônier, C. \& Lerosey-Aubril, R. 2009. Patterns of extinction and recovery of phacopid trilobites during the Frasnian-Famennian (Late Devonian) mass extinction event, Canning Basin, Western Australia. Geological Magazine 146(1), 12-33.

DOI 10.1017/S0016756808005335

Girard, C., Cornée, J.-J., Corradini, C., Fravalo, A. \& Feist, R. 2014. Palaeoenvironmental changes at Col de Tribes (Montagne Noire, France), a reference section for the Famennian of north-Gondwana-related areas. Geological Magazine 151(5), 864-884. 
GÜRICH, G. 1896. Das Palaeozoicum im Polnischen Mittelgebirge. Verhandlungen der Russisch-Kaiserlichen Mineralogischen Gesellschaft 32, 1-539.

Kaufmann, B. 2006. Calibrating the Devonian time scale: A synthesis of U-Pb ID-TIMS ages and conodont stratigraphy. Earth Science Reviews 76, 175-190. DOI 10.1016/j.earscirev.2006.01.001

Kin, A. \& BŁAżEJowski, B. 2013. A new Trimerocephalus species (Trilobita, Phacopidae) from the Late Devonian (Early Famennian) of Poland. Zootaxa 3626(3), 345-355. DOI 10.11646/zootaxa.3626.3.3

Klapper, G., Feist, R. Becker, R.T. \& House, M.R. 1993. Definition of the Frasnian/Famennian stage boundary. Episodes 16(4), 433-441.

Lazreq, N. 1992. The Upper Devonian of M'rirt. Courier Forschungsinstitut Senckenberg 154, 107-123.

Lerosey-Aubril, R. \& Feist, R. 2012. Quantitative approach to diversity and decline in late Palaeozoic trilobites, 535-550. In TALent, J.A. (ed.) Earth and Life. Global biodiversity, extinction intervals and biogeographic perturbations through time. Springer. DOI 10.1007/978-90481-342861_16

LütKe, F. 1968. Trilobiten aus dem Oberdevon des SüdwestHarzes, Stratigraphie, Biotop und Systematik. Senckenbergiana lethaea 49(2-3), 119-191.

Matern, H. 1927. Mitteilungen über die Oberdevon-Fauna der Dill-Mulde. Senckenbergiana 9(6), 252-260.

Matern, H. 1931. Das Oberdevon der Dill-Mulde. Abhandlungen der Preußischen Geologischen Landes-Anstalt, neue Folge 134, 1-139.

Maximova, Z.A. 1955. Trilobity srednogo i verchnego devona Urala i severnych Mugodzar. Trudy Vsesojuznogo nauchnoissledovatelskii Geologicheskii Instituta, N.S. 3, 1-263.

McCoy, F. 1849. On the classification of some British fossil Crustacea with notices of new forms in the University collection at Cambridge. Annals and Magazine of Natural History, Decade 2, 4, 161-179, 300-335, 392-414.

McNamara, K.J. \& Feist, R. 2016. The effect of environmental changes on the evolution and extinction of Late Devonian trilobites from the northern Canning Basin, Western Australia, 251-271. In Becker, R.T., Königshof, P. \& Brett, C.E. (eds) Devonian climate, sea level and evolutionary events. Geological Society London, Special Publication 423.

Münster, G.G. 1842. Nachtrag zu den Versteinerungen des Uebergangs-Kalkes mit Clymenien von Oberfranken. Beiträge zur Petrefakten-Kunde 5(16), 112-128.

Osmólska, H. 1958. Famennian Phacopidae from the Holy Cross Mountains (Poland). Acta Palaeontologica Polonica 3, 119-148.

Osmólska, H. 1963. On some Famennian Phacopidae (Trilobita) from the Holy Cross Mountains (Poland). Acta Palaeontologica Polonica 8, 495-523.

Perna, A. 1915. Upper Devonian trilobites from the environs of the town Vierkhnie-Uralsk. Mémoires du Comité Géologique $138,1-58$.

Pfeiffer, H. 1954. Der Bohlen bei Saalfeld/Thür. Beiheft zur Zeitschrift Geologie 11, 1-105.
Pfeiffer, H. 1959. Neue Beobachtungen und Funde aus dem Saalfelder Oberdevon. Geologie 8, 262-279.

Richter, Re. 1856. Beiträge zur Paläontologie des Thüringer Waldes. Erster Theil. Denkschriften der kaiserlichen Akademie der Wissenschaften, mathematisch naturwissenschaftliche Classe 11, 87-138.

Richter, Re. 1869. Das Thüringische Schiefergebirge. Zeitschrift der Deutschen Geologischen Gesellschaft 21(2), 341-393.

RichteR, R. \& Richter, E. 1923. Systematik und Stratigraphie der Oberdevon-Trilobiten des Ostthüringischen Schiefergebirges. Senckenbergiana 5, 59-76.

Richter, R. \& Richter, E. 1926. Beiträge zur Kenntnis devonischer Trilobiten. IV. Die Trilobiten des Oberdevons. Abhandlungen der preussischen geologischen Landesanstalt, Neue Folge 99, 1-314.

Richter, R. \& Richter, E. 1931. Unterlagen zum Fossilium Catalogus, Trilobitae. V. Senckenbergiana 13, 140-146.

Richter, R. \& Richter, E. 1955. Oberdevonische Trilobiten, Nachträge. 1. Trilobiten aus der Prolobites-Stufe III. 2. Phylogenie der oberdevonischen Phacopidae. Senckenbergiana lethaea 36(1-2), 49-72.

Richter, R., Richter, E. \& Struve, W. 1959. Family Phacopidae, 462-466. In Moore, R.C. (ed.) Treatise on Invertebrate Paleontology. Geological Society of America and University of Kansas Press, Lawrence.

Roemer, F.A. 1866. Beiträge zur geologischen Kenntnis des nordwestlichen Harzgebirges, 5. Palaeontographica 13, 201-235.

Schrank, E. 1973. Denckmannites caecus n. sp., ein blinder Phacopide aus dem höchsten Thüringer Silur. Zeitschrift für geologische Wissenschaften 1(3), 347-351.

Schülke, I. 1995. Evolutive Prozesse bei Palmatolepis in der frühen Famenne-Stufe (Conodonta, Ober-Devon). Göttinger Arbeiten zur Geologie und Paläontologie 67, 1-108.

TAgarieva, R.C. 2013. Conodont biodiversity of the FrasnianFamennian boundary interval (Upper Devonien) in the southern Urals. Bulletin of Geosciences 88(2), 297-314. DOI 10.3140/bull.geosci.1344

Volk, M. 1939. Das Oberdevon am Schwarzburger Sattel zwischen Südrandspalte und Kamm des Thüringer Waldes. Sitzungsberichte der physikalisch-medizinischen Sozietät 70, 147-278.

Whittington, H.B. \& Kelly, S.R.A. 1997. Morphological terms applied to Trilobita, 313-329. In KAESLER, R.L. (ed.) Treatise on invertebrate paleontology. Part O. Arthropoda 1. Trilobita, revised, 1: Introduction, Order Agnostida, Order Redlichiida. Geological Society of America, Boulder and University of Kansas Press, Lawrence.

Ziegler, W. 1962. Taxonomie und Phylogenie oberdevonischer Conodonten und ihre stratigraphische Bedeutung. Abhandlungen des hessischen Landesamtes für Bodenforschung 38, $1-166$.

ZIEGLER, W. 1971. Conodont Stratigraphy of the European Devonian. Geological Society of America Memoir 127, 227-284. DOI 10.1130/MEM127-p227 